\title{
Teología Espiritual
}

\author{
1. Ordo Amoris
}

"Quien posee el Ordo Amoris de un hombre posee al hombre. Posee respecto de este hombre, como sujeto moral, algo como la fórmula cristalina para el cristal" (M. Scheler, Ordo Amoris).

¿Qué decir del peso de la concupiscencia, que nos lleva al abismo, y de la elevación del amor por medio del Espíritu Santo? Mi peso es mi amor: él me lleva adonde quiera que vaya" (S. Agustín, Confesiones, $13,10)$.

Amad a vuestros enemigos, favoreced a los que os odian... Sed perfectos como vuestro Padre celestial es perfecto" (Mt. 5,44-48).

El amor divino se ha derramado en nuestros corazones por medio del Espiritu Santo que se nos donó" (Rom. 5, 5).

Dios es amor.( I Jo. 4,8).

Ama, y haz lo que quieras" (San Agustín).

\section{LA SITUACION}

1. Teologia de hombres.

Según la definición nominal, teologia es una disciplina que trata de Dios y también del hombre y del mundo sub ratione Dei. No se identifica con la Revelación, pero es una actualización de la misma, es decir, una traducción e interpretación del mensaje revelado en la ideología y lenguaje de cada siglo. La actualidad exige hoy que 
la teología sea antropológica y sociológica ${ }^{1}$. Y con eso está dicho todo, en relación con un pasado, que hoy nos parece infantil y pretencioso.

Pero no está dicho todo, si nos referimos al futuro o al presente. Como el Segismundo de Calderón, en La vida es sueño, el hombre hace continuas preguntas, que no tienen respuesta. Es un espíritu absoluto, una autoconsciencia; pero es un ser relacional, que viene trabado desde su raíz con Dios y con el mundo 2. Parece un proscrito, arrojado a una "región de desemejanza", un extranjero o desterrado; y parece la luz del mundo y la sal de la tierra, un enterrado, "en-elmundo". Se le llama rey de la creación e imagen de Dios; se le llama gusano miserable, caña pensativa ${ }^{3}$. Camina abrumado por su culpabilidad y responsabilidad en la existencia, y camina humanizándolo todo, convirtiendo el caos en cosmos. Se presenta amarrado al banco y al remo de la existencia; y se presenta satánico, rebelde, blasfemo. Se dice que "vive sin vivir en sí", y se dice que es un mero "instinto de Thánatos". Este hombre, visto sub ratione Dei, trata de organizar su teología espiritual, o su espiritualidad teológica 4 .

En efecto, los objetos conmueven su corazón y sus pasiones. Con frecuencia no sabe si tales conmociones tienen sentido, o cuál es el sentido de tales influencias. ¿Hay un orden, una intencionalidad, una finalidad en ese comercio cordial? Y si lo hay, podrá el hombre imprimir en su ánimo ese orden, de manera que pueda hablar de "amor ordenado? ¿Pođrá la razón humana colaborar en la revelación, de manera que pueda hablarse de una "teología espiritual"?

1. Gusdorf, G., Traité de l'existence moral, Paris 1949.

ThIELICKe, H., Der Evangelische Glaube, Tübingen 1968, p. 7.

Sorokın, P.A., Las filosofias sociales de nuestra época. Madrid 1956.

Muñoz, A., Persona humana y sociedad, Madrid, 1955, p. 95.

Laín Entralgo, P., Hombre y cultura en el s. $X X$, Madrid 1957.

PRWYWARA, E., Ringen der Gegenwart, 2 vols. Augsburg, 1929.

DUMERY, H., Die Ungeteiltheit des Geistes, München 1959.

SheEN, F.J. Peace of Soul, N. Y., 1951. The philosophy of Anxiety, p. 16ss,

MARCEL, G., Schöpferische Treye, München 1964.

MOELler, Ch. Humanismo y Santidad, Barcelona, 1967.

BARTH, K., Mensch und Mitmensch, Göttingen, 1954.

DupuY, M., La philosophie de M. Scheler, 2 vols. Paris 1959, p. 67.

Paupert, J. M. Peut-on être chrétien aujourd'hui? Paris, 1966. p. 67

2. Zubiri, X., Naturaleza, historia, Dios, Madrid 1944, p. 437s.

3. Pascal, B., Oeuvres complétes. Au Seuil, Paris 1963, p. 506, etc. Parpert, Fr., Philosophie der Einsamkeit, München 1955, p. 50.

4. KIERKEgaARd, S., Discours chrétienes, Neuchâtel 1952, p. 45. 


\section{Espiritualidad teológica.}

La vida espiritual no puede reducirse a un capitulo de alguna ideología (psicología, sociología, filosofía, teología), sino que es una praxis, una postura estable, o un estilo de pensar, decir y hacer, una ascética ${ }^{5}$. La primera herejía de nuestro tiempo es el racionalismo, que trata de reducir la vida a ideología, en el orden teórico o en el orden práctico. El hombre actual sabe que sin esas ideologias superiores no podría vivir; pero vivir es algo más que hacer teología teórica o práctica. Puesto que el problema de la vida sólo puede discutirse en la frontera de Dios y en la frontera del mundo, es necesaria una teología para construir una espiritualidad humana ${ }^{6}$. Unicamente hay que exigir que la teología no sea "racionalista" o herética.

La segunda herejía de nuestro tiempo se llama anacronismo o quijotismo. Consiste en la pretensión de vivir en el pasado, estimando que el pasado era mejor que el presente, y que es preciso pensar, hablar y hacer como recomiendan los libros de caballerías. Tal herejía hace reir a unos y llorar a otros y Cervantes lo denunció genialmente: mientras se discute sobre molinos de viento, un pueblo se hunde en el descrédito, en la miseria y en la impotencia.

Hay todavia un quijotismo, que consiste en vivir en el futuro, en lugar de vivir en el presente. Es una esperanza enloquecida, utópica, propia de las novelas de ciencia y ficción. En el manicomio y en la calle encontramos tipos de ambas especies de herejía quijotesca: gentes que viven en el pasado, y gentes que viven el futuro. Contra ambas herejías se dijo ya en la antigüedad: age quod agis, vive en el presente!

El presente reclama una teología antropológica y sociológica, pero científica. Las realidades son "fenómenos": por ende, se nos obliga a comenzar por una "fenomenología espiritual". Y como se trata de una praxis, lo que importa es cambiar la vida, no contemplarla. La contemplación y la acción son necesarias, pero de modo que vayan conjuntadas. Sólo de ese modo la espiritualidad será teológica y la teología será espiritual.

5. Multitud de psicólogos, sociólogos, fllósofos y teólogos pretenden colonizar a la Ascética y a la Mística.

6. Benzo, M., Sobre el sentido de la vida, 2 ed. Madrid, 1972, p. 201. GUSDORF, l.c., p .7s. 


\section{Existencialismo sociológico.}

El problema espiritual podría llamarse simplemente "libertad". ¿Existe realmente la libertad? ¿Qué es la libertad? Ya que la ciencia y la filosofía se declaran incapaces de explicar de dónde puede salir la libertad en un mundo físico, hemos recurrido a la teología, sin renunciar a los auxilios de la ciencia y de la fllosofía. Comprobamos que en el reino de la física, las situaciones se definen por sus "causas"; en cambio, en el reino de libertad, las situaciones se definen por sus fines, por las intenciones o proyecciones del sujeto mismo. El sujeto humano no es pasivo sino activo, es decir, libre. El mundo de la mera física queda excluido ya que el hombre no se reduce a física.

Pero, naturalmente, el hombre tampoco es libertad omnímoda y total. La física (o biología) no lo es todo, pero es una gran parte de la existencia. Quizá es excesivo reducir la existencia a una "dialéctica", que en el fondo es física o biologia, mera articulación fysisdynamis-télos. Pero nunca podremos eludir una dialógica, es decir, una articulación de la física con el reino de la libertad. El hombre no es mera libertad, sino libertad disminuida, enjaulada en la física. Pero es libre: se gobierna por sus fines, por sus utopías, esperanzas, intencionalidades; por eso es siempre un plus ultra, una "potencia" que quiere llegar al "acto", y que llegará, si lo que llamamos "orden objetivo" es realmente orden.

De ese modo podemos ya tomar dos puntos de partida. Ante todo, el hombre es irreductible al mundo, y nunca será mundo: será siempre algo más que mundo; será utopía, paraíso futuro: todo materialismo dialéctico es una pura ilusión, un "opio"; el único elemento válido del marxismo es el sueño de un "paraíso futuro", un milenarismo. Pero, en segundo lugar, el hombre es irreductible a Dios, nunca será un dioș: en cuanto espíritu encarnado, tiene que vivir en el reino de la física y de la biologia, y quedar condicionado, hipotecado, como Zeus o los dioses de Homero.

La sociología actual urge el problema, exponiéndonos la gravedad de nuestra situación espiritual: vivimos en régimen de explotación y opresión, en un desorden constitutivo. Nos ofrece la ironía como arma, y la teología negativa, como método: denunciar abusos y cincelar, para formar?.

7. THIELICKE, H., Theologie und Zeitgenossenschaft. Tübingen, 1967, p. 258. 
4. Entre Dios y el mundo.

El hombre es "en-el-mundo", pero vive sometido al "orden-deDios". Cuando cobra consciencia de ambos "principios" vive entre Dios y el mundo. Dios y el mundo no son para el hombre espacios neutrales $\mathrm{u}$ objetos de contemplación, sino principios constitutivos. Incluso puede el hombre llegar a la convicción de que el mundo es la voluntad de Dios. Por eso, el hombre nunca podrá entenderse a sí mismo. Se ve como principio absoluto, como autoconsciencia, como memoria: puede vivir pensando en sí mismo, soñando, delirando, sin objeto alguno, embriagado, hundido en su mundo interior, incluso en su infierno, como nos muestra hoy el reino de las drogas, y como nos lo demuestran los manicomios. Pero sabe que es inútil tirar coces contra el aguijón, ya que es esencialmente relacional y condicionado: para emborracharse necesita drogas, y al salir de la borrachera necesita médicos y gentes caritativas ${ }^{8}$.

Este hombre es "desterrado" en la tierra. Aquí radica su opción. En virtud de sus intenciones privadas, puede optar por ser el extranjero de S. Pablo, que "no tiene ciudad permanente" o el Extranjero de Camús que vegeta entre nosotros como la mala yerba. Puede acentuar uno de los dos tipos de "destierro"; puede intentar armonizarlos o contraponerlos hasta que se rompa la tensión. En el fondo, cada hombre tiene que optar, y lo que importa es que sepa lo que hace cuando toma partido.

Este es el drama. Vivir entre Dios y el mundo significa considerarse como "enviado de Dios al mundo". Ese drama tiene un doble aspecto. Por un lado cabe decir como Acab: "no tentaré a Dios", es decir, "me parece excesiva arrogancia creerme enviado de Dios; yo

8. El Vaticano II denunció "el mundo sin Iglesia y la Iglesia sin mundo".

LaVelle, L., De l'Acte, Paris, 1946, p. 105 y 140.

Brunton, P., La Sagesse du moi supreme, Paris, 1969, p. 110.

STEFrES, J.P., Christliche Existenz immiten der Welt, Düsseldorf, 1947. STUECKEBERger, H.M., Christliches Handeln, St. Gallen, 1946, p. 159.

LAVELLE, L., De l'Etre, Paris 1947, p. 195s.

LE SENNE, R., Obstacle et valeur, Paris Aubier, sin fecha.

GuSDORF, G., Memoire et personne, 2 vols. Paris 1951.

- ID, La découverte de soi, Paris 1948.

MOREL, G., Le sens de l'existence s. St. J. de la Croix, Paris 1960.

GEIGER, L.B., Philosophie et spiritualité, Paris 1963.

GUIBERT, $\mathrm{H}$. de., Theologia spiritualis, Roma 1946.

LEWIS, G., Le problème de l'inconscient et le cartesianisme, Paris 1950

HartManN, N., Ethik, 3 ed. Berlin 1949. 
soy humilde y me contento con representarme a mi mismo"; también cabe decir: "Aquí y ahora, Dios soy yo mismo", como el Gran Inquisidor de Dostoyewsky. Ese sería el aspecto negativo o abstracto del drama en sus extremos. Pero el aspecto positivo y concreto es ser "intermediario" entre "nuestro Dios" y "nuestro mundo". Dios amó tanto a la tierra que la pobló de hombres, pero hay hombres que contaminan la tierra, en lugar de salvarla, olvidando sus líneas fronterizas y olvidando que son ordenados a la tierra ${ }^{9}$. Tenemos que servir a dos señores; eso no es contradecir a Cristo, ya que hay dos modos de servir ${ }^{10}$.

\section{Existir.}

Ex-sistir significa sistere extra causas, vivir libre y consciente entre la posada y la patria, pagando la pensión. pero trabajando en los problemas de la posada. No se trata de "una noche en una mala posada", como decía burlonamente santa Teresa, ya que la posada es toda la vida, una noche en la que nos jugamos la patria misma. Es cierto que no podemos suprimir ni mutilar la reminiscencia y la nostalgia de la patria; tenemos que comprender y perdonar a esos místicos que tienen prisa por morirse y estar con Cristo. Los que no tenemos tanta prisa, tenemos que existir aquí, en la posada toda nuestra vida, quemar nuestra vida en la posada. El concepto de posada es pues imperfecto, ya que hay posadas definitivas. $Y$ quien viene a la posada, sólo para explotarla, se llama "picaro"

Dentro de una teología actual, son evidentes dos tendencias antagónicas. La teología espiritual está interesada en esa polémica. Pero advierte que los términos utilizados (conservador, retrógrado, cavernícola, medieval, escolástico, o bien modernista, liberal, desviado, avanzado, revisionista, etc) son un arte de denigrar, calumniar, con

9. Gogarten, Fr., Der mensch zwischen Gott und Welt, Stuttgart 1956 p. 7.

DEMPF, A., Filosofía cristiana. El hombre entre Dios y el mundo, Madrid 1956.

GOGARTEN, l. c., p. 123.

CABA, P., La presencia como fundamento de la Ontología, Madrid 1956.

10. "Orden" es "disposición de las partes de un conjunto, de modo que cada parte tenga su propio puesto y cometido" (San Agustín). Ordenar el amor significará pues, ordenarse a sí mismo en el cosmos, dando a cada cosa el amor que se le debe.

11. Pablo VI repite constantemente la necesidad de ajustar ambos extremos, la "revelación" y la "actualización". 
la conciencia tranquila, suponiendo que el fin justifica los medios. Como por otra parte es inevitable la polémica, algunos estiman que lo mejor sería decir teología $A$ y teología $B$, tomando como punto de referencia el cartesianismo, que inicia la época moderna. Todos sabemos que esta distinción es ya definitiva. El negarla significaría ya en principio una mala intención, y de ese modo se simplificaría el problema de la lucha entre "innovadores" y "conservadores" ${ }^{2}$.

Esa distinción, que obliga a definir el concepto de existencia en sentido propio, no significa aceptar el sistema de Descartes, Kant, Hegel, Husserl, Heidegger, como tampoco significa aceptar el sistema de Aristóteles, Avicena, Averroes, o las formulaciones cristianas de los Mutakalimum. La religión cristiana tiene que pagar tributo a la cultura reinante, y sólo tiene sentido dentro de esa cultura. $\mathrm{Y}$ sin embargo, el cristianismo, que paga bien sus tributos, ex-siste. $\mathrm{Y}$ eso deben hacer todos los cristianos, ex-sistir ${ }^{13}$.

\section{El pronunciamiento actual.}

El hombre actual muestra una rebeldía notoria, demasiado comprensible. Sabe que ha sido victima de comercio, abuso, engaño, de parte de los que utilizaban en vano el nombre de Dios, contraviniendo gravemente al primer mandamiento. Se siente reprimido y explotado, y no admite que el pleito se ventile en griego o en latín, sino en lenguaje comprensible y claro. Tiene en su poder el material histórico, critico, escriturístico, patrístico, lingüístico, cultural, literario, y estima que la fecundidad del cristianismo se debe, no a los inquisidores, sino a los revolucionarios: Pedro, Pablo, Agustín, Tomás, Molina, Suárez...

Resulta hoy cómico hacer comulgar de rodillas a un cristiano, cuando los demás comulgan de pie, o poner a las mujeres un velito precioso de seda en la frente, para que no sean como las "criadas que comulgan descaradamente". Hoy es difícil engañar al hombre moderno con cuentos de viejas, hablando del valor divino de lo humano, que termina en mercantilismo, burguesía y la consabida picaresca ilustrada. Cuando los Santos Padres decían que lo humano tiene valor divino se referian a las criadas y a los nuevos cristianos, no a los explotadores domesticados. No es difícil explotar la victoria

12. Threldcke, Der Ev. Glaube, p. 22.

13. Asi se diferencian Actualización y acomodación. 
del "hombre moderno"; lo difícil es ser hombre moderno, es decir, vivir en nombre de Dios al servicio del mundo, y no al servicio del egoísmo individual o corporativo.

La actitud de protesta parece inevitable en la situación actual del mundo y del cristianismo. Pero en el fondo, en esa protesta se adivina el amor, el cariño, el deseo de que se corten los abusos, se abra el corazón, se ame a Dios y al prójimo de verdad, sin opresión, sin explotación, como Cristo nos enseña. La paz es la tranquilidad del orden; cuando no hay orden, la paz es una maldicićn del cielo, y por eso Cristo trajo la espada y no la paz. La paz de Cristo es otra cosa, no es la paz del siglo, el "pescar a río revuelto", que algunos cristianos han tomado hoy como consigna. Es normal que el hombre actual sea rebelde y vaya al pronunciamiento. En el “¡Bien venido, Mister Marshal!" se sabe de antemano que los platos rotos tenemos que pagarlos todos. En el drama: los listos se aprovechan, y todos pagamos luego los platos rotos! ${ }^{14}$.

14. En este sentido habló Pablo VI del "fin de la era constantiniana". 


\section{EL METODO ${ }^{15}$.}

\section{Método humanista.}

Hay diferentes métodos de enfrentarse con una espiritualidad o teología espiritual. Los dos principales se reducen hoy al humanismo y a la religión, si tomamos ambos términos en sentido totalitario. El humanismo moral, el existencialismo ateo y el humanismo político, en su empeño de "liberar al hombre de Dios", sostienen que el hombre es el valor máximo, y no hay ningún otro por encima de él. Es el método de los gigantes y de los titanes: Cuando estos colosos trataron de escalar el Olimpo, para someter a los dioses, comenzaron a acumular "montañas": cada una de ellas era un escalón, que facilitaba el éxito de la guerra. Y los "valores humanos" son hoy otras tantas "montañas", que se sustraen a Dios y que se van escalonando, para luchar contra Dios. Estos titanes son soñadores: asumen su responsabilidad, el riesgo de su destino, crean los valores, como fin de su propia acción. Se indignan cuando oyen hablar de un "orden objetivo", leyes, valores previamente establecidos, hombres que son simples ejecutores de planes ajenos, sistemas de garantías contra riesgos, alienación, esclavitud, determinismo simulado ${ }^{16}$.

Es verdad que a veces hallamos descripciones desgraciadas de ese "orden objetivo": hacen bueno el juicio crítico de los humanistas ateos. Los llamados "objetivistas" suelen presentarse como gigantes también: "acumulan montañas sobre montañas, para llegar a Dios, no para combatir, sino para hablar en nombre de Dios. Piensan que Jahvé es un Dios de las montañas" (III Reg. 20,28). Su método es perverso.

Frente a esos malos "objetivistas", están los que practican una "subjetividad" o interioridad objetiva: entran en sí mismos a practicar la espeleología, siguiendo el consejo de san Agustín: "no vayas

15. Tratamos aquí de una disciplina experimental, pero que debe atenerse a otras disciplinas superiores, psicología, sociología, filosofía, teología, etc. El método será pues, experimental, pero sin perder de vista esas disciplinas superiores, o fuentes de espiritualidad. Cfr. GuIBERT, $l$. c., p. $17 \mathrm{~s}$.

KIERKEGAaRd, S., Vie et régne de l'amour, Paris 1946, p. 13.

16. Teóricamente, habría un método más allá del "humanismo", el "absurdismo" (Malraux, Sartre, Camús, St. Exupery), extremando la línea de Nietzsche, Fr., Jenseits von Gut und Böse, 1886. Cfr. Somn, P.H., L'homme en procés, Paris, 1950, p. 5ss. Pero finalmente, todos regresan al humanismo. Cfr. Gusdorf, Traité... p. 193. 
afuera, vuelve a entrar en ti mismo... y si descubres que eres mudable, trasciéndete"! Ese es el buen método de la teología espiritual: escuchar los pasos que resuenan en la propia gruta interior, cuando pasa Dios por ella. En cuanto a los gigantes, sólo Don Quijote llamaba gigantes a los molinos de viento ${ }^{17}$.

\section{Método del fariseo}

Fariseo es el hombre que está seguro de representar a Dios y organiza un "partido de Dios". Su buena intención y su estrechez mental son evidentes. Su problema sería legítimo, bien entendido; pero, mal entendido, significa que Dios es secundario: lo importante es el partido de Dios. Es el método propio de los sistemas totalitarios. De este modo, en el momento en que se presente Cristo vivo, estalla el conflicto.

El conflicto de Cristo con el fariseo es ejemplar y sirve para siempre. El fariseo pidió cuentas al Bautista, en nombre del partido: “Quién eres tú?”. El Bautista eludió el proceso inquisitorial, y Cristo trató también de eludirlo. Pero el fariseo, que se consideraba representante de Dios, declaró la guerra a Cristo: lo asedió, lo provocó, lo combatió en privado y en público, de frente, noblemente. Llegando la ocasión, se concertaba con los saduceos y herodianos. $\mathrm{Y}$ Cristo tuvo que replegarse, hablar en parábolas, retirarse, peregrinar cerca de las fronteras de Israel, por Filistea, Fenicia, Siria, Pentápolis, para esconderse en el desierto de Efraim, a esperar una ocasión de entrar en Jerusalén con aires mesiánicos. Logró realizar su esperanza y entró en Jerusalén el domingo de Ramos. Pero los fariseos meneaban la cabeza ante su temeridad: eso significaba su sentencia de muerte. No había más remedio que facilitar a los saduceos la elimininación de este Cristo, que no ingresaba en el partido. Y el fariseo constituyó la "opinión pública", que condenó a muerte a Cristo. Es un método directo, fanático, cargado de buenas intenciones, pero erróneo, en cuanto que, como dice san Pablo, quiere imponer al mismo Dios una "justicia de hombres".

17. En este sentido trabajó bien la así llamada y discutida "escuela francesa" iniciada por el Cardenal Pedro de Berulle (1575-1629), siguiendo una cierta inspiración agustiniana. Cfr. STolPE, S., Die christliche Phalan, Stuttgart, sin fecha: Henry Bremond. 
La primitiva cristiandad pudo comprobar las ventajas y desventajas del método farisaico. Muchos fariseos (pensemos en san Pablo), reconocieron al final a Cristo, y creyeron en él. Prestaron a la naciente Iglesia un servicio esencial, con sus meditaciones del AT., con sus Midraschim Peser, con su celo de Dios, con sus virtudes humanas aprovechadas por la gracia divina. Pero el fariseo seguía siendo peligroso también en el cristianismo, como lo pudo comprobar san Pablo. Continuaba siendo "judaizante" ${ }^{18}$.

\section{Método del saduceo.}

Anás es denominado por Flavio Josefo, "el sabio". En efecto, era el ideal de su partido, único partido que podía gobernar en las circunstancias aquellas, entre los romanos colonizadores y los judíos, humillados y ofendidos. En un momento de conflicto, Anás defendió a su pueblo contra los romanos. y éstos le depusieron; pero él lo había previsto con sabiduría: a) se había convertido en un mártir del bien común de su pueblo; b) había entregado el Pontificado a sus yernos, hijos, y subordinados, de manera que continuaba siendo el gobernante, el estadista, el superior mayor. Anás no creía en la inmortalidad, ni en los ángeles, pero recogía los doblones del gazofilacio, y "gobernaba" a discreción. La última palabra la pronunciaba siempre él. $\mathrm{Y}$ por eso era un sabio.

Este es el método típicamente político, un método de gobernantes. El partido de los saduceos, está constituido por una aristocracia convincente. Sus enemigos terminan confesando que lo mejor es que los saduceos gobiernen; saben sonreir, adular, mentir, traicionar. Incluso, si se derroca un partido de saduceos, sube al poder otro partido de saduceos. El saduceo es el que huele los "signos de los tiempos", el que aprovecha la oportunidad, el que flota en todas las aguas, el que forma el partido, reclutando los "valores" de los demás partidos; es el que siempre calla, el que gobierna por medio del secreto. Anás se había apoderado de los mandos, y callaba. No se le menciona en las luchas y debates evangélicos: sonreía ante las contiendas farisaicas, ante los zelotas, romanos, herodianos y soldados de Pilatos. En todas esas peleas de niños, mostraba siempre sus manos limpias.

18. S. Pablo parece más benigno que los demás cristianos con los fariseos (Rom. 10,2), pero se dio cuenta de lo que significaba "judaizar" (Gál. 2,14). 
Cuando el "caso" de Cristo tomó volumen, el saduceo abrió el expediente de rutina. Cuando se perfiló una amenaza contra el orden público, el saduceo sentenció: "No sabéis nada; es preciso liquidar a ese tipo, para que no comprometa a la gente". La entrada de Cristo en Jerusalén, con todo el simbolismo de un triunfo mesiánico, se le presentó como signo de los tiempos. El saduceo se puso al habla con Judas, y el secuestro de Cristo pudo realizarse, organizarse la sentencia de muerte, seguida de la crucifixión ${ }^{19}$.

\section{Método de Pilato}

El método de Pilato es propio de los diplomáticos. Buscan la paz, pero no la de Cristo, sino la de Roma; buscan el orden público; no el de Cristo: sino el colonial; buscan la justicia, no la del reino de Dios, sino la de Tiberio César. Para conseguir esos fines, Pilato utilizaba la diplomacia romana, tomando el mundo como es. Todos sus métodos se cifran en la escena del Ecce Homo. Creyó que un golpe de habilidad lograría satisfacer a todos, dando al pueblo a escoger democráticamente entre Cristo y Barrabás: el pueblo prefirió a:Barrabás. Pilato no logró satisfacer a nadie y su nombre habría caído en el olvido, si los cristianos no siguieran repitiendo: "padeció debajo del poder de Poncio Pilato".

Al tratar Cesbrón de analizar el método de Poncio, advierte que no se trata de arqueología. Hoy hay fariseos, saduceos y Pilatos como en tiempo de Cristo, y siguen utilizando los métodos antiguos. En el caso de Barrabás, insinúa Cesbrón que también hoy hay que escoger continuamente entre Cristo y la burguesía, a la que representaba el Barrabás.

Los métodos de Poncio llegan a obligar a los cristianos a elegir, pero en tales condiciones, que con frecuencia sale ganando Barrabás. Las habilidades de Poncio no bastan para evitar la confusión reinante: de ese modo, los cristianos eligen a Barrabás cuando creían elegir a Cristo.

Cesbrón señala cinco de las principales habilidades metódicas: ensoñación, evasión, optimismo, providencialismo, buena conciencia, y política del deber de estado. Frente a esas habilidades surge la estampa del Ecce Homo. Al confundir los actuales cristianos sus pro-

19. El tipo del saduceo cristiano es conocido de todos. 
pios valores con los valores burgueses, se alistan, se concentran, luchan y mueren por la influencia bancaria, por la influencia universitaria, por la influencia política. Manejan bien las armas y son valientes, pero ya no saben a quien sirven. $Y$ todavía se creen que son más listos que los hijos de las tinieblas ${ }^{30}$.

4. Método de Cristo.

Cristo revelaba el reino de Dios y su justicia. Pero, para alcanzar ese objetivo, ponía como método la cruz, diciendo: "el que quiera, que cargue con la cruz". Los primeros cristianos sabían qué es la cruz, y así hablaban de mártires y de martirios. Pero en la era constantiniana, la cruz se utilizó para rematar las coronas de los príncipes civiles y eclesiásticos. Los tiranos políticos se defendieron tras un Lábaro, y en cuanto a los príncipes eclesiásticos se lamenta Cesbrón: "un obispo revestido de ceremonia, lleva encima diecisiete piezas o accesorios, mientras que Cristo llevaba una sencilla túnica inconsútil: ése es el índice de la inflación que padece la Iglesia". De ese modo, el método de Cristo queda sometido a revisión y critica.

El ingenio popular ha acuñado el refrán que dice: "tras la cruz está el diablo". Es otra exageración, pero quiere decir: manejan la cruz los "covadongos", los que reconstruyen castillos feudales, los tiranos que repiten con Napoleón: "no puedo gobernar a mi capricho, si la Iglesia no urge a sus fieles la obligación de obedecerme como representante de Dios"; la manejan los revolucionarios, aventureros, aprendices de brujo; la manejan los gobernadores civiles y eclesiásticos; hasta parece que el diablo pone gran empeño en manejarla para sus fines.

Decir pues; que el método de Cristo es la cruz, es decir poco. Se necesita comprobar la madera de la cruz: si hoy se reunieran todos los lignum crucis, sobraria madera para hacer una cruz de Cristo, otra del buen ladrón y otra del mal ladrón. Interesa pues, tan sólo una cruz que sea la de Cristo. Es una cruz que hace palidecer: habla de kenosis y nekrosis, de aniquilación y de mortiflcación, para conseguir un reino de Dios y su justicia, para lograr el triunfo de Dios. Durus est hic sermo. Como diría Sta. Teresa, para seguir a Cristo, es preciso "tragar la muerte" ${ }^{21}$.

20. Cfr. Cesbron, G., Liberez Barabbas, Paris 1957.

21. De ahí vino la sátira popular:

En tíempo de las bárbaras Naciones 


\section{Método del cristiano.}

El método de Cristo necesita actualización incesante, para comprobar la autenticidad de la cruz. Esa actualización se verifica mediante la "voz de la conciencia", ante los "signos de los tiempos". "Mientras peregrinamos lejos del Señor, nuestra conciencia es para nosotros más presente que el mismo Dios" ${ }^{22}$ ¿ ¿Y acaso esa conciencia no es la voz del mismo Dios? De este modo, el método del fiel cristiano es el Soliloquio: el cristiano dialoga con su conciencia, la cual oculta su rostro. El tema del diálogo será siempre la cruz de Cristo, frente a la interpretación del fariseo, del saduceo, del herodiano, del zelota, sicario, o guerrillero, y del soldado mantenedor del orden de la colonia romana. No se trata de un diario íntimo, a lo Amiel, sino de espeleología cristiana, que Heidegger expresaba asi: "¿Quién me interpela? ¿Es Dios, es el mundo, es mi propia alma?"

Ya es un gran progreso despegarse del mundo, y penetrar en la propia espeleología. Pero, cuando eso se logra, hay que discernir. Quizá la voz que se oye en la propia Espelunca no es la voz de Dios, de la ratio, de la conciencia, ni del mundo: quizá es la voz del estómago, del vientre, de la vesícula biliar, o del pulmón. Hay, en efecto ventrílocuos maravillosos, que traban diálogos sorprendentes. Eise método del ventriloquio es muy diferente del soliloquio: no habla ni del Reino de Dios y su justicia, ni tampoco de la cruz de Cristo.

San Agustín, descontento de su propio Soliloquio recurrió al método de la Confessio, que es algo mejor. Confesar es dialogar con Dios mismo, en cuanto testigo, actor y juez de nuestra propia vida. La existencia aparece así, no como un privilegio, sino como un alistamiento para llevar cruces: la existencia misma es una cruz, quizá la de Cristo. Ese diálogo con Dios acerca de la propia cruz y de la propia responsabilidad suele llamarse angustia, y con mucha razón. Quien no alcanza al nivel de la angustia, no ha penetrado bastante en sí mismo. Pero los santos se han esforzado por mostrarnos cuán

colgaban de las cruces Ios ladrones; pero, al llegar el siglo de las luces, del pecho del ladrón cuelgan las Cruces.

El método de Cristo es la Revelación, a la que corresponde por parte nuestra la fe. Para eso vino del cielo y todo lo demás nos lo dio por añadidura. Mas para la vida espiritual, lo importante era mostrar cómo el aparente fracaso de su Pasión y muerte, era en realidad una exaltación y triunfo sobre el Maligno. 
dulce e íntima es esa angustia cristiana. El método de la Confessio no lleva a la náusea de Sartre, sino al amor de Teresa de Jesús ${ }^{22}$.

\section{Método del aprendiz de brujo.}

En la actualidad hay muchos aprendices de brujo, que vislumbran el triunfo de los revisionistas y se suben a la trasera del Carro de la Victoria, sin certificados de estudios, sin obras, sin experiencia. Citan a Karl Rahner, Congar, Chenu, Danielou. Ni tienen la menor idea de la génesis de la Nueva Teología, ni conocen sus estudios acerca de los Santos Padres y de la Tradición cristiana. Se imaginan que se puede ser brujo, sin alma de brujo, y que todo consiste en pronunciar "abracadabra". En cuanto se les presenta la ocasión desencadenan las energías de la naturaleza, sueltan el toro o rompen la presa, ignorando lo que puede acontecer, sin saber torear, ni construir presas hidráulicas, ni dominar a la naturaleza, y se llaman "revolucionarios". A los cuales se oponen otros aprendices de brujo... Estos aprendices son hoy la peste de la renovación y de la actualización. Siembran tal confusión, que ya nadie sabe distinguir entre el renovador auténtico y el aprendiz de brujo. El viejo cacique lo utiliza; el viejo integrista lo utiliza. Son la grama de la renovación, el cultivo de un parasitismo infecundo, una rémora del progreso.

¡Qué hermosas experiencias nos depara la crisis actual! Cuando uno estudia las obras de Danielou o de Congar, acerca de la tradición cristiana, comprende por qué tienen que triunfar. Pero cuando uno ve a los aprendices de brujo, debatiéndose dramáticamente entre las olas, llenos de espanto e impotencia, comprende por qué tienen que fracasar y provocar la catástrofe.

El método del aprendiz de brujo puede ser "intuitivo". Hay en efecto aprendices, que al contemplar el éxito de sus maestros, estiman

22. S. Agustín, Confesiones, $\mathrm{X}, 5,7 \mathrm{PL} 32,782$. Y como Cristo nos llamó a una Ecclesia, los signos de los tiempos son para nosotros voz de Dios, voz social, verbo hecho carne. Así volvemos al concepto de "Vocación" plena. Ya los primeros cristianos vieron que eran muchos los llamados y pocos los escogidos, que el cristianismo tenía demasiados simpatizantes y pocos que cargaran con la cruz, que muchos soñaban levantar torres, pero pocos se sentaban a calcular el coste $y$ dejaban sus torres truncadas. La parábola de las vírgenes necias cuenta mitad por mitad, pero no es una estadística. $Y$ este es el "problema de la aceitera": no basta tener lámpara encendida, sino que es necesaria la aceitera llena. 
que ellos lo harán mejor. Hay también aprendices que estudian los libros de los maestros, pero por falta de suficiente experiencia, incurren en la distracción de la bella Fotis del Asno de Oro, de Apuleyo, que es la ilusión. El pobre Lucio, por el error de Fotis, se convirtió en un asno, en lugar de convertirse en ave volandera. Los aprendices de brujo tienen que someterse al método del buen cristiano ${ }^{23}$.

23. El aprendiz de brujo es el improvisador. Además de la conocida leyenda y del asno de oro de Apuleyo, hay abundante literatura sobre aprendices espontáneos, improvisadores, incluso en el Evangelio, como se ve en la nota anterior. Los escritos apostólicos demuestran que los aficionados eran muchos, pero los profesionales pocos. 
III. EL AMOR

1. :Pasión dominante.

Cuando el hombre llega al uso de razón, se encuentra apegado a los objetos, amasado con ellos, en una suerte de fosilización. Se diría que está "fosilizado" por los objetos, según leyes de los objetos, leyes físico-químicas. Pero pronto se descubre que el amor es tendencia innata del hombre, como el apetito de comer, o el apetito sexual. Los objetos despiertan, provocan el apetito, pero ni lo crean, ni lo estructuran. Así puede decirse que el amor es una pasión, pero es una pasión dominante. Como tal pasión dominante, arranca de la misma naturaleza, de la sustancia del alma, del inconsciente, como una mera energía neutral en el nivel humano brota debajo de la consciencia y de la libertad y por eso decimos que el amor es "ordenable", es decir, que el hombre puede y debe ordenarlo humanamente.

Pero al hombre le acontece como a los objetos. Puede y debe ordenar el amor, pero no puede ni engendrarlo ni estructurarlo radicalmente. Algunos enamorados, defraudados y engañados, escriben canciones con el eterno estribillo “¡no te enamores!”. ¡Cómo si eso estuviera en su mano! O como si quien sufre un cólico, decidiera no volver a comer. Malo es el cólico pero peor es la autofagia o la muerte por inanición. Mala cosa es buscar el amor donde no lo hay, pero cosa peor es no verlo donde lo hay. Eso mismo diriamos sobre las diferencias "bueno y malo", referidas al amor. Algunos se sienten engañados y defraudados por la vida porque hallaron un amor amargo y venenoso; pero no renuncian a vivir, no se excluyen de la vida misma. Es muy triste llamar amor bueno al amor malo, o llamar malo al amor bueno. Pero eso depende de un "orden en el amor".

El hombre con uso de razón se siente, pues, obligado, tal es su primera y última obligación, a ordenar el amor, en lugar de criticarlo, condenarlo, adularlo o explotarlo. Esa obligación es tanto más grave, cuanto que el hombre cuenta o debe contar ya con la eternidad. Al acabarse la vida, todo fenece; manet autem charitas: sólo quedará el amor ${ }^{24}$.

24. Darío, R., Prosas profanas, Madrid 1927. El reino interior, p. $168 \mathrm{~s}$. 
2. ¿Dos amores?

El amor radical es una simple energía neutral, epicena y ambigua. ¿Cómo es que produce frutos buenos y malos, de manera que "al árbol se le conoce por sus frutos"? (Lc 6,44). Parece que se trata, no de dos árboles, sino de uno sólo; por eso, no se distingue el árbol por su raíz, sino por sus frutos. La raíz es la misma pero los "injertos" son diferentes. No queremos decir con eso que los frutos: o los injertos se definan por los "objetos formales", porque un sujeto ame objetos buenos o malos. Queremos decir que el injerto es la intención, buena o mala. No basta amar una cosa buena, hay que amarla bien.

No se trata aquí de proclamar una "moral de intención". En efecto, es evidente que tenemos obligación de amar las cosas buenas. ¿Y qué son las cosas buenas? Para no alargarnos, diremos con Rubén Darío: "divinamente blancas y castas, pasan esas siete bellas princesas. $\mathrm{Y}$ esas bellas princesas son las siete Virtudes". Tenemos que amar las cosas bañadas en los valores, bellas, buenas, verdaderas, justas, perfectas.

Del mismo modo debemos odiar los objetos malos. $Y$ para no alargarnos, diremos también con el poeta: "bellamente infernales, llenan el aire de hechiceros beneficios, esos siete mancebos. $Y$ son los siete Vicios, los siete poderosos pecados capitales".

Todo eso es muy claro. Lo malo es que el cristianismo nos enseñó a ver que "hay viciosas virtudes" y "vicios virtuosos", a pesar de los objetos formales. San Agustín hablaba de los espléndidos vicios de los romanos y el Evangelio nos habla de "vírgenes necias". Otra vez, vemos la diferencia entre la física y la libertad. El lirio del campo y el ave del cielo son siempre lo que deben ser, y así aman lo que deben amar y odian lo que deben odiar. Pero el hombre no es nunca lo que debe ser; no sabe cómo debe amar y cómo debe odiar. $\mathrm{Y}$ ya que no basta un solo fruto bueno o un solo fruto malo, sino que se nos exige una ley de frutos buenos o malos, hablamos de injertos sobre una sola y única raíz. El árbol es de raíz neutral, pero diríamos hoy, "al injerto se le conoce por sus frutos". $\mathrm{Y}$ el injerto es la intención, cuando es estable y permanente, no una veleidad ${ }^{25}$.

25. KIEREEGAaRd, l. c., p. 145. 
3. El deber de amar.

En el cristianismo se nos presenta el amor en forma de mandamiento: "amarás al Señor tu Dios, y al prójimo como a ti mismo". Según la teología del A.T., es fácil entender la primera parte, ya que "amar a Dios" significa servirle, mantenerse en la alianza, desechar todos los ídolos, reconocer a Dios como Señor absoluto del mundo y del yo. Mayor dificultad hay para entender la segunda parte, ya que muchos preguntan "quién es mi prójimo" y "por qué, dónde, cuándo, cómo debo amar a mi prójimo". Por eso se dio la norma: "como a ti mismo".

Vemos el carácter paradójico del amor. Platón trató de explicarlo con una alegoría: el día del nacimiento de Afrodita, los dioses celebraron un banquete; el néctar corrió con profusión, y los dioses se embriagaron. Poros, el exuberante, ebrio de néctar, salió a holgar al jardín, y se tendió en el césped. En ese momento llegó Penia, la mendiga, al jardín, y se tendió junto a Poros: así concibió de él al amor. El amor es, pues, hijo de la miseria y del emporio, de Penia $y$ de Poros.

Platón queria poner de relieve algo más que el carácter femenino y masculino del amor. Explica, pues, que, por parte de madre, el amor busca la satisfacción personal, el bienestar, la belleza, la salud, los valores todos, ya que va mendigando; en cambio, por parte de padre, es generoso, pródigo, derrochador, y se entrega por complacer a los demás, para enriquecerlos con sus valores. Por parte de padre, marcha victorioso y radiante, cazador, filósofo, mago, artista. Es un semidiós, nacido de un dios y de una mujer, y por eso no es mortal ni inmortal: nace y muere en un día, pero renace y vuelve a morir en ese día. El término que lo caracteriza es, no "posesión", sino "fecundidad", ya corporal, ya sobre todo espiritual, que es la propia de los mejores hombres y mujeres, poetas, inventores, políti$\cos$ y reformadores.

He ahí por qué es necesario un mandamiento externo e interno a la vez para "ordenar el amor". Podría ser eso fácil para amar a Dios. Pero para amar al prójimo "debidamente", deberás amarlo "como a ti mismo" ${ }^{26}$.

26. Allers, R., Das Werden des sittlichen Person, Freiburg i., Br. 1935. Platón, Symposion, Les Belles Lettres, Paris 1941, p. 201-211. 


\section{Amor cristiano.}

Nygren ha exagerado e incluso falsificado los textos bíblicos. A pesar de eso, su separación entre "eros" y "agapé" ha hecho fortuna, y eso indica que ha acertado en lo principal. Dios es, pues, " $A g a-$ $p e ́ "$, amor desinteresado, tanto en proceso trinitario, como en el creacional y reparacional. Si el hombre ha de ser perfecto como el Padre celestial, deberá ser agapé, amor desinteresado.

En el misterio trinitario, el Padre engendra al Verbo. En el mis terio de la creación, el Verbo creacional se hace carne, habita con nosotros, y hace de mediador universal, por Agapé, por amor desinteresado. En el misterio reparacional, el Verbo hecho carne y sangre, nos redime; pero nos exige que ordenemos nuestro amor, es decir, que toda esa corriente de amor que recibimos de Dios, la devolvamos a Dios, valiéndonos de los objetos que amamos. $Y$ eso es el amor cristiano, que obliga a amar a todos los hombres y finalmente al "enemigo", que es ya el colmo del amor. Algunos ortodoxos exagerados se han sentido obligados a amar incluso a Satanás, que es el mayor enemigo; hasta se han preguntado si Dios no amará a Satanás.

La revelación cristiana sacudió los cimientos del llamado "orden natural". Los griegos proponian al hombre la física como criterio para ordenar su amor. Los judíos proponían una ley sacral, y una justicia de hombres, que no rebasaba los límites de la justicia legal: es la Torah, pero interpretada por las escuelas jurídicas. No era fácil reducir tales posturas a un "mandamiento"; por eso, los estoicos griegos encargaban al hombre que contemplase el cielo e imprimiese en su corazón el "orden celeste"; los judíos encargaban al israelita meditar la Ley, leer a los Rabinos, e imprimir en su corazón millones de preceptos legales.

Cristo cortó por lo sano, ofreciéndonos un "orden nuevo". Nos dijo que éste es el orden que debemos imprimir en nuestro corazón, no el orden de los estoicos o el orden de los judíos. Sólo dentro del orden nuevo podremos hablar de autenticidad o inautenticidad,

Nygren, A., Eros et agapé, Paris 1944.

SCHELER, M., Ordo amoris, Madrid 1934.

El Evangelio de $\mathbf{S}$. Juan diferencia el amor que viene del cielo del que viene de la tierra; al mismo tiempo, impone la fe, porque no vemos ni a Dios, ni al Verbo, ni a la Iglesia: sólo vemos "prójimos", en los cuales descubrimos el cielo. 
de amor ordenado o desordenado. Nuestro orden es ser hermanos de Cristo, hijos adoptivos del Padre, pero con una "adopción mística", fundada en la sangre de Cristo, no con una adopción legal, adopción de papeles mojados ${ }^{27}$.

\section{El orden nuevo.}

¿Disolvió Cristo el orden antiguo, o lo perfeccionó? Según la fórmula "non veni solvere, sed adimplere ( $\mathrm{Mt}$ 5,17), el "orden nuevo" no era una creación, sino una restauración e integración. Se daban por buenas la revelación natural de los griegos, y la Ley de los judíos, pero se advertía a todos que, en virtud del pecado de la humanidad, era necesario superar la física y el legalismo, si se quería renovar la relación viva del hombre con Dios. Lo que interesaba era renovar al hombre, no renovar problemas de física o de "justificación". Ordenarse físicamente es cosmología y jutificarse con garantías y patentes es asunto de comerciantes y notarias. Cristo quería renovar el corazón del hombre, sanarlo, curarlo, eliminar el viejo corazón de pedernal, que quiere justificarse, a pesar de todo, o regularse a pesar de todo, para poder implantar un orden nuevo de humildad, sumisión, misericordia, perdón mutuo o recíproco, unidad de amor. Cristo quería un "corazón de carne", no justificaciones o legislaciones. De nada nos han servido las luchas modernas entre maniqueos y pelagianos tradicionales. La cultura actual ha demostrado que muchos se llaman maniqueos y son pelagianos, mientras que muchos que parecen pelagianos son maniqueos; ha demostrado también que en ambos casos se trata de una exageración o extremismo, y que es lamentable el que se califique a los que se mantienen en el medio por relación a uno de los extremismos, juzgando tan sólo si se aproximan más a los maniqueos que a los pelagianos o al contrario, más a los pelagianos que a los maniqueos. Nada hemos ganado con tales discusiones, que carecian de sentido cristiano, porque faltaba lo esencial, el amor cristiano, el orden nuevo. Ojalá haya terminado para siempre esa crítica o protesta, madre de los cismas, que quieren justificarse en lugar de confesar.

¿Cómo ha logrado la cultura actual hacernos ver el infantilismo de los maniqueos y de los pelagianos? De dos maneras: a) Mostrando la insondable profundidad del corazón humano; b) mostran-

27. Gogarten, l. c., p. 12.

OPPEN, D. von., Das personale Zeitalter, 4 ed. Stuttgard, 1965. 
do su vulnerabilidad el tendón de Aquiles de cada hombre. Pensemos en los medios audiovisuales, o en los ambientes. La naturaleza es manipulada contra la naturaleza. Nadie nos hace violencia o coacción, pero los filtros y drogas son ya violencia y coacción ${ }^{28}$.

\section{Pecado original.}

La explicación de esa paradoja radica en el pecado original. No se niega la revelación natural, pero se afirma que esa revelación se hizo impracticable e ineficaz por la quiebra del pecado que se llama peccatum naturae. Era necesaria la restauración realizada por Cristo. En virtud de esa situación, que unos llamarán normal y otros anormal, la libertad humana resulta impotente para afrontar el problema del amor. El amor tiene entre los hombres mil clases de enfermedades, debilidades y achaques. S. Agustín ponia el ejemplo del inapetente: desearía tener apetito, no lo tiene; quiere querer, y no puede alcanzar el apetito espiritual; explicaba su propia conversión al cristianismo como aparición de una libertad o amor enérgicos en la entraña de su corazón. Y si eso se dice ya de la misma presencia del amor y del odio, ¿qué habrá que decir acerca del amor bueno y malo? ¿Cómo explicar la fórmula de S. Agustín: "comencé a amar lo que odiaba y a odiar lo que amaba, pasando de un sistema malo a un sistema bueno, que cambia el amor malo en bueno?

Es verdad que también ese concepto de pecado original puede utilizarse como instrumento de propaganda, como medio audiovisual de persuasión y así se hizo en la Reforma Protestante, en contra de la advertencia agustiniana: noli tenebrare tenebras tuas: no entenebrezcas todavia más tus tenebrosidades". Es exagerado convertir el pecado original en un Deus ex machina, del que se echa mano para convertir la creación divina en una obra de Satanás o del pecado.

Pero es también claro que la articulación natural fysis-dynamistelos no funciona como ley natural y dialéctica. Se habla de una "deficiencia constitutiva" (Heidegger), como fórmula filosófica de explicación. Se habla también de un "misterio de lo sobrenatural" (De Lubac). Conocidas son las controversias provocadas por Bayo y Jansenio en un ambiente aristotélico, y las exageraciones a que dieron lugar los malentendidos: el hombre quería presentarse a Dios con el estatuto de su "natura humana" para hacer reclamacio-

28. Blanchard, P., Sainteté aujourd'hui, Lyon 1954. 
nes, protestas y demostraciones. Todo eso pasó, pero corremos el peligro contrario: negar la existencia del pecado original ${ }^{29}$.

\section{Amor y catarsis.}

¿No será excesivo reducir todo el campo de la vida al amor, o ampliar el concepto de amor a toda la conducta humana individual y social? No hay exceso alguno, si el problema se plantea correctamente.

En efecto, es ya común considerar las cuatro pasiones fundamentales (amor, odio, esperanza, temor) como formas fundamentales del amor: el ordenar esas pasiones será simplemente ordenar el amor. San Agustín llevó más adelante la amplificación, al definir las cuatro virtudes cardinales o morales como formas cardinales de amor: prudencia es amor prudente, justicia es amor justo, fortaleza es amor fuerte y templanza es amor templado. De ese modo, el amor natural, como energía y motor originario, impera también en la vida humana, en el reino de la libertad.

Tal amplificación ha suscitado controversias, siempre que el problema se plantea mal. Por ejemplo, si esa visión del amor se compara con el aristotelismo, en el cual cada virtud se define por su "objeto formal", aparece una contradicción: sería excesivo confundir la esperanza con el temor o con el odio, alegando que se reducen al amor; sería asimismo excesivo confundir o identificar la justicia con la limosna o con la virginidad, alegando que tales virtudes son meras determinaciones o atributos del amor. Por consiguiente, tales "reducciones" son falsas: dentro del tratado moral De virtutibus es necesario distinguir las virtudes y vicios por el objeto formal, distinguiendo así lo que es bueno y lo que es malo "objetivamente".

Pero la Teología espiritual no se contenta con virtudes abstractas y objetivas, ya que sabe que existen vicios virtuosos y virtudes viciosas. Por lo mismo, y sin pretender practicar "reducciones obje-

29. Ligier, L., Péché d'Adam et peché $d u$ monde, 2 vols., Paris 1960. El Protestantismo actual, fuera de la escuela de K. Barth, va suavizando sus posturas. Habla de una Revelación natural, y de una Etica cristiana con facilidad. Dostoyewsky, en la leyenda del gran Inquisidor (Hermanos Karamazov) describe la cruz de la libertad. 
tivas", prefiere estudiar el punto de vista del sujeto, la intención o intencionalidad de ese sujeto. Tampoco se trata aquí de buscar una "moral de intención", que llame bueno a lo malo o malo a lo bueno. Se trata de saber si lo bueno está dañado por una mala intención, o si lo malo está corregido por una buena intención, ignorancia o falta de libertad. $Y$ de este modo, el amor abarca toda la llamada vía purgativa ${ }^{30}$.

30. DE Lubac, H., Le mystère du surnaturel, Paris 1965. Paliard, J., Maurice Blondel, Paris 1950. 


\section{ORDENACION DEL AMOR.}

\section{El ideal}

La voluntad de Dios debería ser el criterio absoluto para ordenar el amor. La dificultad consiste en conocer esa voluntad de Dios, e imprimirla en nuestro ánimo, de manera que nuestra voluntad pudiera coincidir aproximadamente con la divina. Sólo entonces podriamos hablar de un Ethos absoluto, es decir, de un sistema recto de estimaciones y preferencias en el amor: ese criterio absoluto sería el ideal absoluto para comparar lo que realmente soy con lo que yo deberia ser. Mas, ante la imposibilidad de contar con un ideal tan bello, es preciso pensar en otros ideales imperfectos, pero más asequibles.

Hay ideales que son irrealizables para un sujeto en forma genérica: "yo deberia ser asi, pero no puedo serlo, porque soy de hecho... mujer: varón, nórdico, judío, viejo, negro", etc. Hay también ideales irrealizables para un sujeto en forma concreta: "yo deberia ser así, pero no puedo serlo, porque soy... débil, cobarde, enfermo, mal educado, inconstante, etc. Tales ideales son inútiles y perjudiciales. Hay, en cambio, otros ideales que son realizables. Los grandes hombres pueden ser considerados como "modelos", como ideales concretos. Lo malo es que "cuando Dios hace un santo, rompe el molde"; por eso, tales ideales son también hipotéticos.

Subsiste sin embargo, la ley general: los grandes hombres, las grandes acciones poseen un poder de arrastre, porque son atractivos: provocan la admiración y con ello la imitación. El mejor predicador es "Fray Ejemplo" (S. Francisco). Verba movent, exempla trahunt. Hasta los niños imitan a los héroes de la televisión.

El problema no es abstracto, sino concreto. Porque, cuando queremos plantearlo en "nuestro caso" ya nuestros padres, maestros, confesores, directores, propagandistas, nos han "recomendado" ciertos ideales, que quizá ni nos van a nosotros, ni a la circunstancia en que vivimos. Quizá nos han instalado ya en un falso ideal, y nos hacen correr por una pista falsa. ¿Cómo podríamos aceptar un falso ideal, como criterio para ordenar nuestro amor, o regular nuestra conducta, o nuestro sistema de estimaciones y prefencias? ${ }^{31}$.

31. MILlán, A., El problema del ente ideal, Madrid 1947.

Allers, R., Das Werden... p. 153-191. 
2. Ideal realizable.

¿Cómo podemos saber si un ideal es realizable o irrealizable? Tendríamos que conocer, no sólo el yo, sino también la circunstancia, y eso parece imposible. En la práctica, el problema no es tan difícil. Por ejemplo, para conocer la circunstancia tenemos hoy a nuestro alcance una inmensa información de la psicología, sociología, filosofía y teología actuales. Para conocer el yo, todos tenemos un conocimiento aproximado de nosotros mismos; luego viene el prójimo y nos ayuda con sus críticas; luego entendemos que nuestra libertad está muy restringida; finalmente, el conocimiento de los valores obra como iluminación personal. El problema es, pues, "viable".

Deberemos comenzar por la "teología negativa": el examen de conciencia, la confesión sacramental, las críticas ajenas, etc. nos muestran nuestras "faltas". Suprimir faltas es rellenar huecos. Todos sabemos que curar una dolencia es ganar salud y energía positivas. El problema es difícil y lento: San Pedro juró en la última Cena, y a las pocas horas perjuró: la tentación lo había derribado. Dios le "tentó" como tentó a Abrahán y Job, y lo encontró demasiado dẻbil y soñador.

Es, pues, necesario ensayar, probar. Como dicen los ingleses, Try only! Cristo habló de los cálculos que debe hacer un hombre, cuando va a levantar una torre, o dar la batalla a su enemigo (Lc 14,28). Hay que ser prudentes y no proceder a lo loco. Los primeros cristianos comprobaron que muchos se adherían, y luego volvían al vómito. Todo eso no impide el ensayo y la prueba, cuando se espera el éxito y cuando se toman las precauciones y providencias necesarias. Es más, será preciso mantener la fórmula “audaces fortuna iuvat", la fortuna se complace en coronar a los audaces. Colón no hubiera descubierto América: si hubiera querido apurar hasta la evidencia sus investigaciones sobre Cipango.

Es necesario, eso sí, tomar las precauciones y proceder con arrojo. Con miedos, vacilaciones, medias tintas, paños calientes, sin confranza en el éxito; todo ideal es irrealizable ${ }^{32}$.

VALlejo NÁJERa, Niños y jóvenes anormales, Madrid 1941. RIBERA, J., La superstición pedagógica, Madrid 1910.

García Hoz, V., Diccionario de Pedagogía, 2 vols. Barcelona 1964.

32. SCHELER, Ordo amoris, p. 123.

Beaudenon, L., La formación en la humildad, 3 ed., Barcelona 1944. 
3. Ideal auténtico.

Es peligroso hablar de ideales. Ese término dirige la atención hacia el sujeto individual y no hacia la circunstancia: se abre la puerta al mercantilismo, autocomplacencia, narcisismo, concupiscencia de mando, de honra, de poder, placer, saber, etc. Esto parece inevitable después de varios siglos de subjetivismo y burguesía, en los cuales el egoísmo trabaja siempre bajo capa de piedad y caridad. Lo único que podemos hacer es desviar la atención hacia finalidades diferentes de las egoístas, ya sean individuales o comparativas: el Reino de Dios, el servicio social, la caridad con el prójimo, etc. El ideal auténtico reposará siempre sobre la base de la humildad personal.

El ideal auténtico no es, pues, nunca una maqueta modelo, que haya de ejecutarse, sino algo que tiene que inventarse: consiste en una relación entre la humildad del sujeto y las necesidades ambientales. El Verbo vino al mundo a cumplir la voluntad del Padre, desde luego: esa voluntad era revelar al mismo Padre y organizar la Iglesia como Reino de Dios dentro de la historia. Del mismo modo, cada persona debe cumplir en el mundo la voluntad del Padre: esa voluntad consistirá en resolver los problemas planteados por el ambiente, por la circunstancia, por las necesidades, abusos, pecados, miserias circundantes. Eso no significa que "el hombre haya sido hecho para el sábado", sino que "el Hijo del Hombre tiene poder también sobre el sábado". Una cosa es el personalismo, y otra el individualismo: aquel es siempre relacional, mientras éste pretende ser absoluto.

El término "servir" es utilizado como criterio para marcar ideales auténticos. En efecto, una cosa es servir al ideal, y otra servirse del ideal. El egoísmo tiene mil disfraces sensibles y espirituales, pero siempre deja entrever que se coloca a si mismo en fin, y convierte los objetos en medios; por el contrario, el amor convierte a la persona en medio para los objetos a los que se sirve. Ese es el problema: servir a Dios o servirse de Dios, servir al prójimo o servirse del prójimo, servir al mundo o servirse del mundo, etc. Sin duda hay un egoísmo ordenado, pero hay otro desordenado ${ }^{33}$.

33. ALLERS, $l$. c.,

BLONDEL, M., L'action, Paris 1893. En dos vols. en 1936 y 1937.

Según el Evangelio, cada hombre es un siervo, un criado de Dios. Se dirá pues, "siervo útil" o "siervo inútil", por relación a los intereses 
4. La humildad auténtica.

Hay una humildad inauténtica, ya que la humildad tiene muchas falsificaciones. Por eso dijo Sócrates: "por los agujeros de tus andrajos, oh gran Kleantes, se descubre una inmensa soberbia". El egoísmo, el resentimiento, la envidia, la venganza, la incapacidad, el fanatismo y aún la ignorancia, muestran por los agujeros de sus andrajos una mal disimulada soberbia. El necio da gracias a Dios, porque ocultó sus secretos a los sabios-soberbios y se los reveló a los humildes, que son él, a su juicio. Por eso Santa Teresa, al afirmar que la humildad es la verdad, se burlaba de los que dan gracias a Dios por unos talentos que no han recibido.

En la escuela de Adler se ha puesto especial cuidado en apurar la fórmula teresiana: "la humidad es la verdad". Se interpreta la fórmula frente a un complejo de superioridad y frente a un complejo de inferioridad. Se parte de la base experimental: cada cual tiene ya una estimación acerca de si mismo, de sus fuerzas y potencialidades. Se engaña quien vive en un complejo de inferioridad o en ù complejo de superioridad; está en la verdad quien tiene sentido de la realidad, y ha medido sus fuerzas en la experiencia. Este es el hombre; cuando es cristiano, reconoce su misión de estar colocado entre Dios y el mundo, y se dispone a realizar la misión entregando al mundo lo que recibe de Dios, en justicia y con la mayor aproximación posible.

La humildad cristiana va mucho más allá: por un lado, se funda en la kenosis de Cristo, así puede repetir: "no yo, sino la gracia de Dios conmigo" (I Cor, 15,10); por otro lado, se siente enviada al mundo para revelar la gloria de Dios. Se diría que la humildad cristiana no es un ideal, sino más bien un complejo de inferioridad. Sin embargo, ahí está la sabiduría del cristianismo: ese cristiano que parece rebajarse, repite con $\mathbf{S}$. Pablo: "todo lo puedo en aquel que me conforta (Filip. 4,13). A la humildad se la reconoce, no por su abatimiento, sino por su audacia, por su valentía, por la gallardía con que se arriesga a las obras grandes, contando con la gracia de Dios. El humilde es un "dios de gracia" ${ }^{34}$.

de la casa de Dios. El inútil, el serve nequam, es automáticamente malo; quizá no es mal hombre, pero es mal siervo, pues no vale para el servicio: puede un reloj ser de oro, y no marcar a las horas.

34. KLUG, I., Las profundidades del alma, Madrid 1954, p. 49-78.

ADLER, A., Menschenkenntnis, Leipzig 1927. 
5. El proyecto vital.

Como "hipótesis de trabajo" podría pasar. Pero sería peligroso tomar ese infantilismo por una "teoria seria". En primer término, nunca sabemos si esta noche nos arrancarán el alma (Lc 12,20). En segundo lugar, en toda hipótesis de trabajo acontece que el trabajo mismo desmonta la hipótesis: y obliga a formular una nueva hipótesis más exacta y seria. En tercer lugar, cada persona pertenece a un conjunto y cobra sentido de este conjunto: sería ridículo que una célula del organismo se inventase un "proyecto vital" para si misma, o para el conjunto. En cuarto lugar, todo el movimiento de la historia humana implica imperfección y azar, o contingencia, elemento imprevisible: Camús hacía "proyectos vitales" y murió de un accidente de automóvil, cuando menos lo esperaba. ¿Quién es el hombre que aicanza madurez y perfección? Muchos mueren en la flor de la edad, cuando más se esperaba de ellos; aun el viejo de cien años, cuando mira hacia atrás, considera su existencia como un fracaso o como una mínima parte de sus potencialidades realizadas: la familia, el ambiente, el grupo, obligan a vivir en posición incómoda, a dejar a un lado nuestra auténtica misión; así nos asombramos de que algunos hombres, que llamamos "grandes" hayan sido capaces de "realizarse".

Por otra parte y por lo general, cuando alguien se hace su proyecto vital, suele ignorar que ese proyecto se 10 han dado ya hecho los demás: el ambiente, la atmósfera, el sistema en que vive, las relaciones personales y sociales. El problema de la libertad real del Kombre queda siempre aqui sin solución. Quizá quien se cree más libre, es el más iluso e inconsciente, un mero juguete de su "escuela", un muñeco que habla. De ese modo por los "proyectos abstractos" crece en el murdo el mal, el poder de la Bestia, por la escasa eficacia de los creyentes (Apoc 13,1-18). Cuando un asceta, por salvar su preciosa alma, según su proyecto vital, deja el mundo a merced del diablo, Este se regocija; le importa poco la suerte de un tonto, si logra dominar el mundo.

Finalmente, no hay posibilidad de un proyecto vital: sólo hay proyectos comunitarios, orgánicos, sociales: todo bien y todo mal

Scheler, M., Wesen und Formen der Sympathie, Bonn 1923.

SPRANGERS, E., Lebensformen, 5 ed., Leipzig 1927. 
de la persona es un bien y mal sociales. La vida personal tiene carácter escatológico y sólo permite "proyectos escatológicos" ${ }^{35}$.

6. El ideal y la conciencia.

Podemos admitir el "proyecto vital" como mera "hipótesis de trabajo", mito relativo, pero útil. Su valor será meramente provisional: lo que importa es la conciencia, el momento presente, los pies colocados en la tierra, las manos puestas en el timón. Quien se obsesiona, mirando a la estrella polar, puede encallar en el bajío. Quien no cesa de contemplar la crestería de la sierra, tropieza en el camino áspero y se desanima. Por lo mismo, es necesario atenerse a la propia conciencia.

Pero, como acontece con la humildad, acontece también con la conciencia. Tiene varias falsificaciones, entre las que descuellan la "conciencia domesticada" y la "conciencia ventrilocua". Hay una conciencia domesticada, que está al servicio del egoísmo y del interés, una suerte de mono sabio, que dice lo previsto y ha sido amaestrada para hablar y callar. Hay también una voz interior, que parece venir de Dios, y viene del vientre, del estómago, de los pulmones, del epigastrio. La autenticidad es fácil de discernir, por lo menos para los demás: tales falsificaciones están siempre al servicio del egoísmo, no del Reino de Dios y su justicia.

La conciencia auténtica brota de la sustancia del alma (no es una potencia aristotélica); dice la verdad al hombre con libertad y elegancia. Habla con autoridad, ya que vive apostada junto a la frontera de Dios, en la misma sustancia del alma; no es un mero instrumento de actividad, una mera "causa instrumental", al servicio del egoísmo. Constituye el puente internacional de la frontera con Dios. En ese puente tiene montadas sus propias oficinas de control, de aduana y reconocimiento. Por su naturaleza y función, supera todas las habilidades de las ideologías, si no se deja envenenar, domesticar o drogar.

El ideal va a identificarse con la conciencia. Cada sujeto es preguntado por su intencionalidad, y ese es el problema esencial. Cuando al sujeto le preguntan qué pretende, qué busca, qué desea, etc. tiene que expresar sus ideales, más o menos confusos. Se ve obligado a "aterrizar", a concretar ideales; a decir con sencillez qué quiere, qué puede y qué debe hacer ${ }^{36}$.

35. Winklhofer, A., Ziel und Vollendung, Ettal 1951.

36. Es curioso el estudio de Goethe, presentado por Scheler y amplifi- 


\section{DESTINO $\mathrm{Y}$ LIBERTAD}

\section{El destino, como imposición.}

Nos encontramos aquí con una confusión de vocabulario en el uso de los términos destino, vocación, sino, sentido, etc. La lengua castellana es exhuberante y barroca, por su Siglo de Oro. Pero hay en ella falta de continuidad: en la actualidad tales términos necesitan nuevos fundamentos. "Destino", por ejemplo, puede significar "el lugar de destino", en el lenguaje actual de los transportes y medios audiovisuales: "Destino, Barcelona; Destino, la juventud", etc. Pero significa también lo que destina, la causa, el mismo sistema de transportes $\mathrm{u}$ orientación de los medios audiovisuales: "este servicio está destinado a..." o "este programa está destinado a..." Nosotros preferimos este segundo sentido, al modo de la Bestimung alemana.

Nuestra opción se opone al barroquismo de la primera interpretación. Se me dice que estoy "invitado" a ser quien debo ser. En realidad estoy "destinado", y no sólo "invitado". "Percibir mi destino" no es imaginarme "adonde me llevan a parar", sino averiguar quién me lleva y cómo me lleva. Sobre esto puedo indagar y averiguar, pero no sé adónde me llevan, cuál es mi sitio de "destino". Por eso, la confusión vuelve, si se acepta el destino como meta: "el destino es una meta que vamos fundando nosotros mismos, a medida que existimos". Camino y meta son lo mismo.

Nuestra opción nos libera de confundir el destino con la vocación o sino, y con el deber y el ideal. Oímos decir: el hombre se siente profundamente libre; se siente ligado (vinculado) a un profundo destino, que le sujeta, pero que le expresa en lo más hondo de su ser y de su existir; se siente llamado a ese destino, como una misión excepcional", etc. El destino es la misión. Porque el hombre no es mera libertad; sino que vienes "destinado". Y lo que nos pre-

cado por Ortega y Gasset. Se ha convertido en un ejemplo clásico, que puede aplicarse a todo sujeto. Pero no se plantea el problema de la "conciencia de Goethe", que es el problema fundamental. 
ocupa en esa destinación es, no el lugar a que nos envian, sino la fuerza con que nos envían. Por eso es posible hablar de heirmarmene y ananke, o también de fatum y destinare: lo que interesa es la ley, no el adresse ${ }^{37}$.

\section{Arrojados al mundo.}

No debemos escandalizarnos de esa fórmula, acuñada por el existencialismo. San Agustín la presentó con mayor dureza, diciendo: "arrojados al mundo a tontas y a locas". A los que hablan de utópicos "proyectos vitales", hay que recordarles los factores:

1. Cuerpo, alma herencia, familia, patria, cultura, clima, etc.

2. Sexo, edad, vitalidad, estatura, potencias, pasiones, biología, etc.

3. Constitución física y psíquica, temperamento, carácter, complejos, conflictos, inconsciente, intenciones oscuras, resentimientos, etc.

4. Circunstancias, estructuras, ambiente, secta, etc.

Sería inútil recurrir al concepto de providencia para anular el concepto de destino: la providencia misma se convertiría en una jaula de nuestra existencia: ni un gorrión, ni hoja de árbol, caen en tierra sin permiso del Padre celestial. Una fe cristiana, viva $y$ minuciosa, tiene que santificar y bendecir los barrotes de la jaula existencial, dentro de la cual opera libremente el hombre como un canario. De ese modo, aparece el absurdo de los "proyectos vitales".

Pongamos ejemplos. Los Apóstoles, S. Pablo, S. Agustín, S. Benito, S. Francisco, S. Ignacio, etc. ¿tenían algún proyecto vital, o tenían la menor idea de su "figura ideal"? Ni por asomos. Comenzaron a abrirse camino. Su camino no significaba "la meta"; sino más bien la necesidad de caminar con buena intención. Alabamos a los que triunfaron, es decir, a los que tuvieron "éxito"; olvidamos a los que no triunfaron, aunque quizá merecieron mucho mejor el triunfo. Condenamos la "ética del éxito", pero la practicamos y vivimos.

37. CABA, La presencia, l.c. Esto significa que el problema sólo nos interesa en cuanto el destino pueda "destinar", es decir, determinar o condicionar la libertad humana. Es hermosa la metáfora del camino pero es peligrosa; el camino de un "segador" es segar y la meta es "lo que ha segado". Fácilmente el camino se convierte en un "paseo", no en un "quehacer". Conviene, pues, aceptar plenamente el concepto de destino, no para eludir el concepto de libertad, sino para prantear el problema humano. 
La literatura sapiencial está escrita por los triunfadores. Viene a decirnos que es posible y aún fácil descubrir "el orden primordial", el sistema de leyes que rigen el mundo humano. Los libros de Job y del Eclesiastés nós ponen en guardia contra tales ilusiones. Dios tiene sus planos. Pero nos envía al mundo a levantar una fábrica, sin darnos los planos... ¿Cómo podremos levantar los planos y la fábrica? ${ }^{38}$.

\section{Espectáculo.}

Continuamente se oye decir: "no hagas cosas extraordinarias; haz extraordinariamente bien las cosas ordinarias". ¿Qué hermosura! Algunos críticos agudos han aplicado (analogia) la espiritualidad a la plaza de toros, para acentuar la diferencia entre el sustantivo y el adverbio, entre "lo bueno" y "bien". Supongamos que cada sujeto es un torero; se encuentra frente al toro del destino, y tiene que lidiar como "espectáculo de hombres y de ángeles". Esta analogia nos gusta, aunque no nos guste la "fiesta nacional".

En primer lugar, vemos la vanidad del lenguaje usual. No podemos decirle a un torero: "no hagas cosas extraordinarias, haz extraordinariamente bien las vulgaridades". Ese torero tiene que saber cuál es su sitio en la plaza, cuál es su función y cuál es la faena que en cada momento tiene que ejecutar. Todo eso tiene que pensarlo frente a un público, que llena los graderíos, y frente a unas leyes de tauromaquia que conocen todos los entendidos.

El torero es libre y puede hacer lo que quiera, pero dentro de la plaza y dentro del plan del empresario que es Dios. Puede recurrir a los trucos, que nunca faltan; puede recurrir al tremendismo temerario, jugándose la vida, pero demostrando que no sabe lidiar legítimamente; puede dar capotazos hábiles, y distraer al público, ajustándose a un orden objetivo de funcionario y profesional; puede fi-

38. Tenemos pues, condicionamientos físicos, biológicos e históricos, que son otras tantas jaulas. Sólo dentro de ellas podemos hablar de libertad. Y aun eso no basta. En efecto, la libertad se ve comprometida también con atractivos espirituales. Por qué se convirtieron los primeros cristianos, cuando sólo se les ofrecía la espada, la persecución y la ignominia? Honramos a san Esteban protomártir, pero olvidamos a los anónimos que fueron apedreados, crucificados, apuñalados por los sicarios judíos. Los libros de Job y del Eclesiastés nos previenen: ¿Es nuestra literatura piadosa una "literatura sapiencial,", que va demasiado lejos? No hay que olvidar que flotamos en el misterio. 
nalmente entregarse, arriesgarse, cogerle cariño al toro, lidiarle realmente, enfrentarse con él, dominarlo, domarlo, convertirlo en un juguete, y demostrar al público, a los ángeles y a Dios, que hay una gran diferencia entre la bestia ciega y el hombre libre. El hombre no debe someterse al destino, como el torero no debe someterse a la fiereza del toro.

Esto significa que lo importante es tener un "torero" y no un "espontáneo". El problema no se resuelve con consejos pedagógicos: "guiados por las aptitudes personales: el éxito será más fácil, la satisfacción personal más alentadora, el equilibrio entre el interior y el exterior más estable, el servicio social más eficaz..." Magnífico, pero.... ${ }^{39}$.

\section{Lidiar legitimamente.}

La existencia es una corrida, como pensaron Goya y Picasso. Tiene sus causas, motivos de credibilidad, credulidad, empresario, público, estructuras, toreros malos, regulares, buenos y geniales y finalmente el toro. En todo caso, es una comparación excelente, para la brega de la vida.

Es corriente exagerar el carácter dramático de la lidia, el riesgo ante la cornada y la muerte. Puesto que muchos de los que mejor lidiaron, cayeron ensangrentados en la arena, se destacan la valentía, el riesgo y un cierto desdén ante la mala suerte. Hay también una visión de la existencia como riesgo deportivo, como desafío al destino, como provocación a la fortuna, como confianza en la buena estrella. En el fondo, es una visión recta: sin la buena suerte, sin la gracia divina, poco se podrá hacer en este mundo de trampas y cepos.

Sin embargo, la lidia legítima no es tremendismo o temeridad, sino ciencia y arte. Para ponerse delante de un toro, se necesita una preparación adecuada; se necesita ser un diestro. Se corre el riesgo, desde luego, pero "legítimo": un riesgo diferente del que corren el chulo, el loco, el espontáneo, el aficionado. El diestro conoce

39. Muchos sujetos, científicamente colocados en la Estructura y en pleno derroche de privilegios, fueron a parar al pilón. Otros, mal colocados e indefensos, salieron airosos y en hombros. Hay una ley de compensación y supercompensación. Las facilidades adocenan a la gente y las dificultades obligan a "saltar": es el estilo lacónico. Quizá Esparta educaba mejor que Atenas. 
bien al toro y le sigue las vueltas hasta dominarlo, hasta demostrar la superioridad del hombre sobre la bestia, hasta irlo llevando hacia la muerte y lo hace ante el público, convertido en espectáculo del mundo, haciendo ver que el hombre es una figura científica y artistica, que explica la civilización humana: el hombre dominó a la naturaleza, domesticó a los animales, y se hizo señor de esta plaza de la tierra.

En el coso se pone de relieve la dificultad de torear legítimamente. Así debe hacerse, puesto que la brega es difícil. Basta contemplar a un torero y verle hacer: cada faena es una lección para enfrentarse con el propio destino: la preparación, la escuela, el estilo, el señorio, la calma, demuestran que un hombre sabe medir el terreno de la fiera y el terreno propio. Junto al coraje aparecen el arte y la sabiduria. Se dan desplantes, pero bien calculados ${ }^{40}$.

\section{Calma y fe.}

Aunque algunos diestros caen ensangrentados en la arena, se trata de un accidente. En todos los órdenes de la vida acontece eso. Un médico decía: "no sé cómo podemos mantenernos en pie, teniendo tantos órganos y funciones y tantas enfermedades para cada uno de ellos, tantas amenazas y microbios en el aire, en el agua, en los alimentos, en la sangre y en la carne". A pesar de tantos riesgos, la vida se propaga y avanza. Una de las estampas más sugestivas del Evangelio es la barquilla de Pedro, zarandeada por las olas. Cuando se derrocha tal dramatismo en esa pintura, se deja entender que los primeros cristianos no comprendían cómo la barquilla podía mantenerse a flote: pero han pasado XX siglos, y la barquilla sigue ahí flotando y zozobrando como siempre. Y la Iglesia debe su eterna juventud a los bandazos.

Tienen pues razón los psicólogos que hablan de compensación y supercompensación. Las excesivas facilidades adocenan al hombre mientras que las dificultades le obligan a "saltar", a mantenerse ágil. Sin duda que ocurren "accidentes", pero no pueden servir de norma general. La norma general es lidiar legitimamente con calma

40. Goya y Picasso muestran una excelente analogía entre el toreo y la existencia. Cfr. Conde de las Navas, El espectáculo más nacional, Madrid 1899. 
y con fe, con la convicción de recibir la corona y no la cornada. (II Tim. 2,5).

Eso es valedero también en el terreno de la fe. También la Iglesia es una plaza para la corrida, como S. Pablo se complacía en repetir: "He lidiado una excelente brega, he consumado la corrida, he mantenido la fe; espero la corona de justicia" (II Tim 4,7). Y a su discípulo Timoteo le aconseja: "Lidia bien esa corrida de la fe, conquista la vida eterna (I Tim. 6,12).

A veces es casi imposible mantener la serenidad, no dejarse contagiar por el pánico, por el nerviosismo y por las pasiones. Pero la fe ayuda mucho a la calma. No se trata del indiferentismo estoico de la apatía. No. El hombre que se enfrenta con el destino, se opone humanamente al destino; no es el destino, no es la mera fuerza ciega, lo que se impone al hombre. La valentía es compatible con el miedo, con cautela, y en todo caso con la resignación ante lo inevitable ${ }^{41}$.

\section{La prudencia}

Volvemos a la conciencia: No hay pues métodos científicos, automáticos, para "realizarse". La superstición pedagógica, que repite "la ciencia hace milagros" está desacreditada por la experiencia y la observación más elemental. La beatería supersticiosa es el origen de la mayor parte de las "plagas de Egipto", que nos agobian. Nos dominan la organización, las unliversidades, institutos y colegios, los títulos y escalafones; pero con demasiada frecuencia sólo hallamos "hombres de paja". que viven a expensas del sistema, en lugar de servir al sistema. Es pues claro que la ciencia y la técnica no resuelven el problema humano, si bien pueden contribuir a iluminar$10 \mathrm{y}$ facilitarlo.

En sentido contrario, topamos con los fanáticos y desaprensivos, que repiten: "la obediencia hace milagros". Se supone que quien es incapaz de explicar matemáticas, las explicará admirablemente, si al levantarse de la cama se santigua, y si obedece al superior, el cual representa nada menos que a Dios. Tomad en el magnetofón

41. Cuando Frascuelo dio la alternativa a Guerrita, al ver el toro que le había tocado, le dio la primera lección: "dale pocos pases con la mano derecha; en cuanto se te ponga, éntrale con muchos pies, porque está dificultosillo. Anda, que yo estaré a tu vera". Así daba san Pablo la alternativa a Timoteo. 
una clase de matemáticas, dada por alguien que no las conoce, y que obedece a sus superiores, y no necesitaréis pruebas. Tanto monta la beatería científica como la beatería piadosa; ambas son mera superstición.

Nos queda, pues, tan sólo el probabilismo como punto de partida. Pero es suficiente: quien háce lo que puede, no está obligado a más, y pelea legítimamente (II Tim 2,5) ¿Quién podría recriminarlo? No pidió certificados ni patentes al Papa, al Obispo, a los gobernadores civiles, militares o eclesiásticos, al superior mayor del castillo, al superior de la casa, al confesor, censor, director, a los camaradas $o$ al pueblo. No pretendió protegerse, justificarse, consolarse. Corrió su riesgo alegremente, cargado con su cruz. $Y$ a los que le daban consejos les regaló la fórmula de Manolete: "Caballero, las lecciones se dan al pie del toro". Eso significa que además tenía sentido del humor, que es la perfección de la prudencia. Puesto que hay que torear al destino, mejor es torear bien que torear mal ${ }^{42}$

\section{SINO O VOCACION}

1. ¿Sino o mandato?

¿Cabe distinguir entre sino y vocación? En la apariencia, el sino (signum) es sólo una señal, un tau que llevamos marcado en la frente, y por el cual todos nos reconocen: es, pues, un escudo, una bandera, una librea o uniforme. En cuyo caso, si no coincide con la vocación, no nos interesa, pues pertenece a las "señales de la circulación". Pero, al parecer, el sino es algo más que un signo externo una divisa para los demás: viene a identificarse con la vocación, con los signos de los tiempos que cada sujeto percibe para orientar su propia vida o conducta. No un signo, sino una orden, o mandato.

Es algo muy diferente del destino. Este tiene carácter objetivo, físico, determinante. En cambio, el sino es subjetivo, relación consciente entre el destino y la misión. En la escena de la transfiguración, Lucas entiende que Moisés y Elías, seres sobrenaturales, comentaban la Pasión y Muerte próximas de Jesús (Lc 9,30). En esa

42. RIBERA, J., La superstición... l. c. García Hoz, V., Diccionario de Pedagogia, 2 vols. Barcelonà 1964. VALLEJo NÁJERA, A., Niños y jóvenes anormales, Madrid 1941. WINKLHOFER, A., Ziel und Vollendung, Ettal, 1951.

Boros, L., Mysterium mortis, Freiburg i. Br. 1964. 
forma externa, se nos intima la teoría de nuestra propia transfiguración, en la que se nos habla de nuestra pasión y muerte. Los alemanes identifican a veces los términos Einsprechung (invocación, locución interior) y Einleuchtung (iluminación, inspiración).

Por de pronto, es necesario diferenciar bien el sino del destino Además, hay que diferenciar bien la vocación o sino de la "misión". Vocación significa vinculación al mundo, fidelidad a Dios en el mundo, es decir, fidelidad a las circunstancias, bajo la iluminación de Dios. Por lo mismo, es un problema grave y difícil. Implica fidelidad a un pasado, pero con vistas a un futuro. El destino era ya una vocación elemental, en cuanto representaba la voluntad de Dios en el ambiente concreto. Pero ese destino queda desprovisto de su energía física y determinante: se convierte en un abanico de posibilidades. Lo que importa ahora es ligarlo con el futuro, con la misión que yo personalmente tengo que cumplir o realizar en mi ambiente, para realizarme a mí mismo. El destino me orienta, me alude y llama, pero me deja en libertad para optar ${ }^{43}$.

\section{2. ¿Quién habla dentro de mi?}

Mis angustias humanas comienzan al separar mi yo empírico (soy) de mi yo ideal (debo ser, tengo que ser). Hay un yo ideal, que pretende encarnar en mí, que me habla acerca de "lo que debo ser" y de lo que "tengo que ser". Cuando se me dice que "debo ser así", se me habla de una obligación o vinculación "moral": el problema deberá plantearse y solucionarse de acuerdo con la moral; cuando se me dice que "tengo que ser así", me veo ante la ambigüedad: quizá es un problema de física, anunciándome que mi libertad es un mito; quizá es un problema de cálculo y barrunto, anunciándome que terminaré bien o terminaré mal, puesto que se han visto ya muchos casos como el mío; quizá se trata de una confusión, anunciándome que "tengo que ser" lo que "debo ser". Este es ahora mi problema: ¿Qué tengo que ser yo? ¿Quién lo sabe, quién lo manda o determina, o exige? ¿La moral, la biología, la política, la revelación, las brujas de Macbet?

43. Ortega y GaSSET, J., Obras completas, Madrid 1946, IV, p. 402. , ID, Meditaciones del Quijote, Madrid 1957, p. 107.

Unamuno, M., Vida de D. Quijote y Sancho, 6. ed. Buenos Aires 1945. SCHELER, Ordo amoris, p. 114 y 118.

HeIDEGGER, M., El ser y el tiempo, México 1951, p. 310-321.

CABA, P., l. c. p. 161s. 
Los intentos que se hacen para explicarme ese problema son problemas auténticos, pero necesito comprobarlos. El estoico me manda "seguir a la naturaleza": es un problema de física: quiere que me deje guiar por mis gustos y preferencias biológicas; eso me sorprende, ya que el estoico no conoce la naturaleza humana: quizá no sabe que "la dolce vita" nos agrada a todos, y que es la vocación universal. ¿Por qué el estoico no se llama epicúreo? En cambio, el heroicista me manda agere contra, oponerme a la naturaleza; la llamada naturaleza está corrompida y es la peor consejera. El primero me dice: "haz lo que te gusta y acertarás"; el segundo me dice: "haz lo contrario de lo que te gusta y acertarás". En ninguno de los dos casos hallo certidumbre ni garantía alguna: a veces acierto $\mathrm{y}$ a veces yerro. La voz interior es, pues, un misterio. ¿Tendré siempre que preguntarme con Heidegger: "Quién me llama, Dios, el mundo, mi persona? ${ }^{44}$.

\section{Carácter y vocación.}

¿Acaso el carácter determina ya la vocación individual? Se propone el carácter como "mismidad" del hombre. ¿Será tal, que se pueda contar con él de antemano, para sacar fichas y hacer encuestas? Hoy necesitamos saber por anticipado cómo tiene que pensar, decir y hacer cada hombre, nuesto que el carácter es el "modo de ser" de cada uno. Es lo que decían los escolásticos: homo determinatus ad unum.

Tal pretensión parece verosímil, puesto que hay que contar con las virtudes (hábitos, rutinas). La vida sería insoportable, si en cada momento el hombre tuviera que plantear el problema general de su vocación. De hecho, el "pensamiento preconsciente" resuelve el ochento por ciento de los problemas de elección. El inconsciente y el hábito o rutina constituyen nuestra vida en su-inmensa mayoria de acciones, pensamientos opiniones. Tal rutina es meritoria, desde luego, ya que ha sido lograda por repitición de actos, fatigas, angustias y sudores: es nuestra garantía; el volante o rueda que hace el movimiento uniforme, seguro, hasta que se pueda hablar de un

44. Heidegger M., Der Feldweg, Frankfurt a.M., 3 ed. 1962.

Rubio, D.. La filosofía del Quijote, Valladolid 1953.

Véase la nota anterior. Pero también la circunstancia me habla y me obliga a responder a sus demandas. 
ethos: "un ethos que vacila no es un ethos, sino un antojo". Pero es rutina.

Laten ahí la "idea griega", el determinismo, la física, el robot. La fórmula de Pascal "toma agua bendita y embrutécete" se toma tan al pie de la letra, que el sujeto se convierte en un bruto material o espiritual; para excusar ese tipo individualista de su estrechez mental se recurre a la "idiosincrasia", e incluso a la fórmula de Cristo "No se hizo el hombre para el sábado, sino el sábado para el hombre". Pero se trata de un abuso. Supongamos que Cristo hubiera dicho: "No se hizo el hombre para el Reino de Dios, sino que el Reino de Dios se hizo para el hombre", terminaríamos diciendo: "no eres tú para Dios, sino que Dios es para ti". Esto es francamente exagerado, ¿no? $Y$ sin embargo...

Quizá los existencialistas exageran a su vez, al decir: "no hay carácter: eso es una idea griega". En efecto, hemos visto caer los cedros del Líbano, y hemos comprobado que cada Aquiles tiene su tendón débil. Por eso Cristo nos recomendó que pidamos a Dios: "líbranos del Maligno! ${ }^{45}$.

\section{4. ¿A qué viniste?}

El criterio de la vocación deberá, pues, ser, no lo que me convenga a mí, sino lo que demanden de mí las circunstancias, lo que reclamen el Reino de Dios y su justicia en mi ambiente. Ese criterio distingue muchos niveles: ¿A qué he venido al mundo, a mi pueblo o nación, a mi grupo o Congregación, a mi región o ciudad, etc? Todos esos niveles deberán irse subordinando en un contexto general. Así aparece el problema: yo no he venido al mundo por mi pie, sino que me han traido, y quizá me han traído también a otros niveles diferentes sobre los que habria que hablar analógicamente; hay otra voluntad superior a la mía, una voluntad que me intima: "Buscad primero el Reino de Dios y su justicia" (Mt 6,33).

¿Qué significa el Reino de Dios y su justicia aquí y ahora? Se nos acusa a los cristianos de dejar el Reino de Dios y su justicia

45. ALLERS, Das Werden... p. 6.

LoRenzins, G., Caracteriologia y Tipologia, 3 ed. Alcoy 1961.

StERn, A., La filosofía de Sartre y el análisis existencialista, Buenos Aires 1951.

Gusdorf, La découverte...: La notion de Personage, p. 210.

CIRLOT, J.E., El estilo del s. XX, Barcelona 1952. 
para el otro mundo, desentendiéndonos del mandato de Cristo, que sin duda se refiere a este mundo. Se dice que nos refugiamos en "el fin último", para librarnos del "fin penúltimo": nos refugiamos en la eternidad griega para evadirnos del compromiso temporal, de la cruz de cada día; se nos compara a aquel sabio que trazaba círculos en la arena, mientras el enemigo daba el asalto a la ciudad, hasta que los soldados vinieron y le rompieron el compás en la cabeza.

Parece claro que un fin último supone un fin penúltimo, del cual depende en el orden ejecutivo: primum in intentione est ultimum in executione. Parece claro que consigue el fin último el que cubre legitimamente el fin penúltimo. De ese modo, el Reino de Dios y su justicia es una fórmula feliz, que reúne todos los fines. En el orden de la intención, es el fin primero, el que da sentido a todos los demás, la estrella que orienta al barco en su rumbo misterioso. En el orden de la ejecución, es el fin último, el que se consigue realizando los otros fines anteriores. Todo dependerá, pues, de lo que cada uno haya contribuido a establecer en la tierra el Reino de Dios y su justicia. Parece clara la vocación corporativa, liberada de sus mitos. Ese es el sentido cristiano de la vocación: "Trato de alcanzar la medalla de oro de la divina vocación" (Filip 3,14$)^{46}$.

\section{Mi puesto y mi función.}

Ni mi destino ni mi vocación son asunto mío privado o particular: la propiedad privada tiene siempre una dimensión social. Nadie puede ni debe desvincularse del servicio social, hacer la guerra por su cuenta. Esta obligación de justicia implica, al parecer, la obligación de restituir, de manera que se cumple el refrán: non remititur peccatum, nisi restituatur ablatum. Quien defrauda al destino y a la vocación tiene que responder ante Dios, ante el prójimo y ante sí mismo del fraude: tiene que restituir en cuanto pueda. Siempre podrá fugarse por la puerta de servicio, y adoptar la figura del santo prófugo, de uno de esos que se mutilan en el frente para refugiarse en un hospital, o tiran las armas en vanguardia, para atender a los heridos caritativamente en la retaguardia. Pero "nobleza obliga", y esos que se dicen "santos de hospital" carecen, al parecer de nobleza y dignidad personales.

46. ThIELrCKe, Der Evangelische Glaube, p. 453. 
EI destino y la vocación me obligan a reconocer cuáles son en este mundo, (en que me encuentro "arrojado y llamado", o enviado), mi puesto y mi función, cuál es mi oficio. Necesariamente tengo que ocupar un puesto fijo y que realizar un cometido concreto. Tengo que conducirme dentro de una profesión concreta; soy libre de escoger esa profesión dentro de ciertas condiciones: por eso hablamos de "vocación" en el sentido de elección, suponiendo que hay libertad y mérito dentro de una obligación de nobleza. Dentro de cada profesión se puede vivir bien o mal. La profesión es un camino, pero dentro de ese camino hay modos de correr o de andar, y modos de sentarse y dormitar. Unos se arrastran y otros marchan ligeros, con estilo, a paso de andadura. Bene curris, sed extra viam. Abandonaste el puesto, tiraste las armas, y ite llamas santo, porque haces caridad en el hospital? Hay factores que casi determinan el puesto y la función con la misma vocación. Paul Claudel decia: "uno sabe cuál es su vocación, cuando llega a un sitio del que ya no puede literalmente moverse". Pero eso hay que comprobarlo ${ }^{47}$.

\section{Sino y preparación.}

Las categorias fundamentales de la existencia son hacer, tener y ser. El "estar preparado" pertenece al "tener", y se ordena al ser. El avaro tiene cada día más, y tiene cada día con mayor radicalidad y seguridad: asi cae en la trampa, al subordinar el ser al tener: se hace esclavo de los valores que posee y de los apetitos con que los posee. $\mathrm{Y}$ sólo podrá liberarse de dos maneras: a) por el método cínico de Diógenes o de Crates, cuando arrojó sus alhajas al mar, diciendo: "os ahogo para que no me ahogéis vosotras a mi"; b) por el método cristiano, convirtiéndose en "administrador de Dios", reconociendo el carácter social de la propiedad privada.

El término "tener" abarca todo lo que "adviene" al hombre: cul-

47. El caso no es imaginario, sino real: hay quien busca refugios en tiempo de bombardeos: se busca una Congregación para liberarse de una situación comprometida, o se busca una situación libre para librarse de una Congregación, etc. Cfr. KLuG, Las profundidades, ...El concepto de Cuerpo Místico nos da fácilmente a comprender que cada célula, órgano o función trabaja en un organismo: puede ser célula sana o cancerosa, puede entorpecer o facilitar el paso de la gracia divina. Ibsen se muestra obsesionado por este problema (Cfr. IBSEN, H., Dramen, Berlin 1964. Léase especialmente Un enemigo del pueblo, Brandt y El pato salvaje).

SCHELER, Ordo..., p. 117. 
tura, virtud, inteligencia, comprensión, etc. Por eso, el tener (ciencia, prudencia, valentía, responsabilidad, amor) es ya un modo de ser, que se consigue con el "hacer". Quien nada tiene que dar no es nadie. Es curioso que la Iglesia haya propuesto a los teólogos agustinianos como patrón a Sto. Tomás de Villanueva, un limosnero, al que los artistas presentan con una bolsa de dineros en la mano. Es una lección: poseer un capital material o espiritual y disponer de él a cada momento eso es tener y ser. Quien no está preparado para dar, nada puede dar: la fortuna la pintan calva. y sólo la retienen los que pueden cogerla por los cabellos de la frente, cuando se presenta, los que están al quite: To be ready, that's everything! Antes de lidiar legitimamente, hay que ser un diestro, con muchas horas de vuelo.

Este es el drama de la existencia, ya que el caso del "tener" se repite en el hacer y en el ser. Sísifo puso su ideal en llevar hasta la cumbre una roca "imposible" y se creía un Hacedor: eso no es hacer en el sentido de trabajar, sino en el sentido de "ejercitarse" tirando cantos al rio; en sentido contrario, hay quien huye de la acción a la contemplación (Lc 10,42) con ganas de dormir. $Y$ en la categoría del ser hay quien se empeña en ser Dios, o igual a Dios, o representante de Dios ante los demás, etc., pero hay también quien, al no poder ser Dios, se declara en quiebra y bancarrota, como pasión inútil... ${ }^{48}$.

\section{Vocación y sacrificio.}

La vocación es o reclama un sacrificio, un rationabile obsequium ¿Y qué significa "sacrificio"? Significa tres cosas: destrucción, don y sacralidad.

El sacrificio es una "poda". Poda no significa exterminio, sino esperanza de una nueva floración; no significa aniquilación, sino progreso, creación. El podar es un medio, ordenado al fin de promover la utilidad del rosal, o del frutal. El asceta se limita para aprovechar mejor sus energías, sabiendo el resultado de la poda: floración, palingenesia, resurrección.

48. GuSdoRf, G., L'experience humaine du sacrifice, Paris 1948, p. 1. MARCEL, G., Etre et avoir, Paris 1935; KIERKEGAaRd, S., Discours chrétiens. Neuchâtel 1952, p. 113s; SARTre, J.P., L'être et le néant, Paris 1943,16 ed., p. 508 s y 663. 
El sacrificio es también un don. $Y$ el don es simbólicamente: la entrega de sí mismo: cada uno se da a sí mismo en su don. Antiguamente se ofrecían a Dios animales y hombres; el sacrificio humano fue suprimido con el tiempo, pero quedó sustituido por el animal. También aquí el don parece reclamar una "retribución". Caín y Abel esperaban sin duda la "bendición de Dios", cuando ofrecian sus dones al Señor. Algunos piensan que es de esencia del sacrificio esa mentalidad del do ut des (Gusdorf, Marcel). Que eso sea mercantilismo o no, mercantilismo material o espiritual, dependerá de la intención del oferente.

En el caso del asceta, el punto más importante es la sacralidad. Entramos en un mundo "reservado", en el que los ejemplos de este mundo no valen, o sólo valen según una analogía de proporción. En el mundo de lo sagrado se dan efectivamente la fascinación y el terror, el inhorresco et inardesco de S. Agustín. Por eso en este mundo de la sacralidad, el sacrificio tiene caracteres y rasgos muy especiales y propios. La "poda" queda sometida al Reino de Dios, y éste es el que guía la mano del que poda. El don que se entrega a Dios, como símbolo de la entrega personal; sólo será mercantilismo, cuando se trata de superstición, no de religión. $\mathrm{Y}$ la "santidad del sacrificio", o consagración personal tendrá caracteres, que escapan a la ciencia, a la filosofía y a la teología, para internarse en el campo de la mística ${ }^{49}$.

\section{Vocación y amor gratuito.}

Lejos de ser mercantilista, el asceta es víctima del "orden en el amor". Puesto que el ascetismo está más allá del derecho y de la moral, la obligación del asceta es de nobleza y de generosidad gratuitos. El asceta piensa, como Antígona, que además de las ideologías y compromisos políticos, hay ágrapha, leyes no escritas sino inscritas

49. GuSDORF, $l$. c., Aliotta, A., Il Sacrificio come significato del mondo, Roma, 1947; Clauder, A., "Sacrifice", en DTC, XIV, I, 1933 y en Supplement. Ibsen mantiene su Idea fija: la vida auténtica lleva consigo el sacrificio, la cruz: el Dr. Stockmann se consuela al final, al quedarse completamente solo, diciendo: "el hombre más fuerte del mundo es el que llega a quedarse solo; (Un enemigo del pueblo); el Pastor Brandt tiene que sacrificar su felicidad, su propio hijo, su propia vida, y se consuela repitiendo, "io todo, o nada!"; Ekdal (El Pato salvaje) acepta una viđa auténtica, pero al momento aparece la cruz: se destruye su vida familiar y su hija se suicida. Cfr. STERN, A., La filosofía... p. 214). 
en los corazones que muchos no perciben. "Nobleza obliga", pero a solos aquellos que tienen suficiente sensibilidad o dignidad. La "utilidad" del sacrificio ascético no es para el asceta, sino para los otros. Indica, desde luego, una perfección perșonal, pero es en el fondo un estajanovismo espiritual, que se siente responsable y obligado en su comunidad.

Ese amor gratuito no es la prodigalidad animal o física del bonum est diffusivum sui. El asceta no es un incontinente: se da porque tiene motivos de credibilidad, motivos religiosos; se diferencia del bonzo, y del credulón. Sabe que, al sacrificarse y darse amorosamente, se asocia a la redención del mundo, al asociarse a ese Hijo, a quien Dios entregó gratuitamente por el amor al mundo (Jo 3,16). Su amor gratuito es, pues, racional.

Ese amor gratuito es también responsable e inteligente. En efecto, la filosofía moderna trata de convencernos de que todos somos culpables del mal del mundo por acción u omisión, por colaboración o falta de colaboración. Tenemos que repetir con Dimas, el ladrón de buen humor: "nosotros pagamos en justicia, pues nos cobran el precio de nuestras fechorías; pero él no hizo nada malo" (Lc 23,41). $\mathrm{Y}$ si el sacrificio de Cristo se explica por sustitución o solidaridad, el del asceta es hasta cierto punto obra de justicia estricta. Es, pues, una descarga de la responsabilidad de la persona individual y colectiva. $\mathrm{Y}$ es inteligente, porque entra en la intimidad de Cristo, liberándose así de escribas, fariseos, saduceos, zelotas, herodianos, soldados romanos y demás partidos. Vale más la intimidad de Cristo, el entrar amorosamente en su sacrificio, que convertir la casa de Dios en mesa de negocio (Jo 2,16). El amor gratuito, como María, escoge la mejor parte y eso es signo de inteligencia ${ }^{50}$.

50. La metáfora de la "poda y la de la "presa hidráulica" expresan bien el sentido positivo del sacrificio ascético. Cfr. S. Agustín, De div. quaest. q.30 y 31 PL 40,19-21. Así interpreta el Santo la fórmula "te ofreceré un sacrificio voluntario", del Salmo 53: "amo voluntariamente, cuando amo gratuitamente" (In PS. 53, 10 PL 36, 626s). 


\section{LA FIDELIDAD}

\section{El compromiso temporal.}

La relación entre el Reino de Dios y la vocación nos impone la conclusión: "mantener el rumbo" y "saber manejar el barco". Junto a la estrella polar aparece la brega de cada día, el compromiso temporal (Mt 10,38). Dios impone ese compromiso, cuando Cristo invita a tomar la cruz. $Y$ como no interesa ser bueno a mediodía o el lunes por la tarde, sino que es preciso ser cristiano siempre, se imponen el concepto de fidelidad, el concepto de hábito o virtud, el compromiso temporal.

Hay que desvincular esa fórmula de la picaresca que suele acompañarla, y que la ha hecho odiosa o sospechosa. Hay hombres responsables e irresponsables; estos últimos suelen avisar a los primeros: "tú eres un hombre responsable, tú estás obligado a cumplir tu compromiso temporal, a jugarte el honor, el puesto, la vida". Lanzan al responsable hacia la muerte con la alegria de eliminarlo y de ocupar su puesto. Por eso resulta peligroso hablar del compromiso temporal, trampa o cepo para los incautos. Siempre fue muy socorrido llamar héroes a los que convertimos en carne de cañón, o hablar de caridad, cuando la solicitamos.

Una vez separado el compromiso temporal de la picaresca, que suele aprovecharse de él, queda en pie la necesidad de ser fiel al compromiso temporal. Se trata de la acción concreta y cotidiana; por lo mismo, esta fidelidad al compromiso temporal sirve de criterio para comprobar la rectitud de otras formas de fidelidad, más espirituales y discutibles. Tampoco se trata sólo de una acción mecánica, sino de la acción "humana" y religiosa, dentro de un pueblo de Dios. Quien no se siente solidario de su ambiente y de su pueblo, quien no ama a su pueblo y ambiente, no podrá ser "fiel". La fidelidad es ante todo y sobre todo, amor gratuito ${ }^{51}$.

\section{Fidelidad y conflicto.}

La solidaridad nos impone la comunicación en las relaciones externas: educación, trabajo, autoridad, interés. El compromiso tem-

51. González, O., Elogio de la encina, Salamanca 1973.

MARIE-RUdEL, I., La parroquia de los infieles, Barcelona 1955.

GuSDORF, G., Traité de l'existence moral, Paris 1949, p. 292s., y 222s. 
poral exige a veces sacrificios fuertes en la defensa de los oprimidos, de los débiles, de los encarcelados en las cárceles espirituales. La comunicación, por sí sola, es ambigüa; puede ser benéfica o maléfica según los casos: además, hay clases de comunicación: hoy vivimos en una socialización totalitaria $\mathrm{y}$, sin embargo, hay individuos que viven en la más espantosa soledad interior a pesar de la comunicación en las relaciones externas; por otra parte, hay desahogos que explotan a los "responsables", alegando una falsa y cínica mendicidad espiritual o material. Por eso, a la comunicación hay que añadir la participación. La participación es ya comunión personal: compromete a todos y responsabiliza a todos en un compromiso natural y sobrenatural. Es la fórmula paulina: "llevad los unos las cargas de los otros, y así cumpliréis la ley de Cristo" (Gal. 6,2). Es la forma práctica de amar "efectivamente".

La fidelidad supone un conflicto continuo como la misericordia, supone miseria o la paciencia, tentación. Tal conflicto no se produce sólo en el roce con las demás personas, sino también con la comunidad entera o estructura en que vivimos. Toda Institución se basa en un principio de cohesión y participación, de desarrollo, sentido y perfección. Tal unidad se expresa en los términos "concordia" y "unanimidad". Es un principio espiritual; sería inútil sustituirlo por intereses políticos, económicos, sensuales, ambición, poder, gloria, agresividad o rivalidad. La fidelidad va ligada a ese principio. $A$ veces ese principio es tan poderoso que asimila automáticamente a los miembros, como acontece en las instituciones que tienen espíritu (Geist). Pero puede debilitarse tanto, que llegue a desaparecer, produciéndose el separatismo, o la desbandada. Sin el principio espiritual, la corporación se corrompe más pronto o más tarde ${ }^{52}$.

\section{Fidelidad y crisis.}

Aunque toda fidelidad supone conflicto, éste cobra especial importancia en épocas de crisis como la nuestra. ¿Cómo hablar de fidelidad a quien ya no ve la utilidad de su sacrificio personal y no sabe ya a quién está sirviendo? Cuando un sistema comienza a quebrar, la crisis va llegando poco a poco a todos los elementos del sistema. Los elementos que en el sistema antiguo daban valor al sacrifi-

52. Gutiérrez, G., Teología de la liberación, Salamanca 1972, p. 27. Berdiaev, N., Cinq méditations sur l'existence, Paris 1936, p. 115 y 121. 
cio, comienzan a ser discutidos o negados: surge la impresión de que el sacrificio personal carece de sentido.

El problema es inevitable. Podría evitarse, si el organismo, corporación o sistema, hubiera ido evolucionando con el tiempo. Pero si las circunstancias cambiaron, y el sistema se mantuvo rígido, en un fixismo, es ya imposible la fidelidad conflictiva. Supongamos que una esposa quiere ser fiel a su marido, pero exigiendo que su marido se mantenga joven, rico, sano y alegre, como el día de la boda: el desequilibrio terminará en divorcio. Es necesario adaptarse, actualizarse y esto supone una imaginación creadora para irse armonizando con las circunstancias cambiantes de cada día. Ese ejemplo de la fidelidad es excelente para estudiar por analogía cualesquiera tipos de fidelidad, entre individuos, con los grupos, con la sociedad o con Dios.

La crisis actual tiene numerosos agravantes, entre los que destaca el viejo abuso del "institucionalismo", o exageración de las instituciones. La institución exagerada despersonaliza a los individuos, y se hace adorar como Nabucodonosor. Sería pueril negar que hemos padecido siglos de sacralización institucional. Pero ahora, al llegar la hora de la reacción podemos ir a parar al extremo contrario del individualismo exagerado, cuyos abusos venimos también padeciendo desde hace siglos. Por un lado aparece una violenta tendencia a la "socialización" que convierte a los organismos en colmenas y hormigueros. Por otro lado, se defiende el personalismo, alegando el Sermón de la Montaña, y oponiendo a las costumbres de los antiguos juristas el "pero yo os digo". $\mathrm{Y}$ así pululan los reformadores y revisionistas, que pescan a río revuelto ${ }^{53}$.

\section{Muerto el rey, ¡viva el rey!}

El sistema que nos parecía perenne, y aun eterno, se va resquebrajando poco a poco. Habíamos llegado a constituir un "mundo", es decir, un repertorio de preguntas y respuestas, en el que todos sabían lo que había que preguntar y responder. No se necesitaba dis-

53. FouRez, G., "Promises and fidelity in a crumbling culture", en Rév. $f$. Religious, 30 (1971) 1012-1018.

RoYCE, J., The problem of Christianity, 2 ed., Chicago 1968.

RANDY, E., Scheler's Phenomenology of community, Nijof 1966, p. 9396.

OPPEN, Das personale Zeitalter..., p. 22. 
currir mucho, sino tener una memoria regular, para estar al corriente. $Y$ la ciudad alegre y confiada continuaba su vida cada día en plena euforia de normas y doctrinas. Todos sabian cuándo acertaban y cuándo erraban, cuándo pecaban y cuándo se arrepentían. Era como un paraiso, que muchos recuerdan con nostalgia, y tratan de recobrar: no saben que hay dos querubes con la espada flamígera para impedir el regreso.

Esto acontece con frecuencia en la historia, si bien hoy la crisis es más profunda y nos toca más de cerca. Como siempre, el cambio se inició al ponerse a la luz algunas "incongruencias del sistema". Una incongruencia es un linaje de monstruosidad, que no encaja en el sistema: es inútil acudir a las respuestas del repertorio, ya que el monstruo, la "negación" o antítesis, no estaba prevista en el sistema. $Y$ como una incongruencia nunca viene sola, sino que el toque de clarín anuncia la llegada de otras incongruencias, comienzan la lucha y la revolución. Poco a poco se va descubriendo que el viejo sistema ya no sirve ni para preguntar ni para responder, que el sistema entero, como tal, va a desplomarse. Los partidarios de la vieja guardia defienden sus sueños y añoranzas, pero al final, el sistema se desploma. ¿Cuántos sistemas se deplomaron antes que el que nosotros conocimos?

$\mathrm{Y}$ sin embargo, no se puede vivir sin sistema. Es inútil alegar que todos los sistemas son falsos, deficientes y engañosos. La tendencia de los hombres a la unidad, suprema ley del mundo, obliga a todos a comenzar a construir un nuevo sistema, apenas se constata la desaparición del sistema anticuado. $Y$ hoy vamos construyendo poco a poco y con gran angustia el nuevo sistema, que facilitará la vida a las futuras generaciones hasta la próxima revolución. ¿Y a quién tenemos que ser fieles ahora? Sin duda al rey nuevo. ${ }^{54}$.

\section{Fidelidad muerta y fidelidad viva.}

Colocados nosotros entre un rey muerto y un rey vivo, tenemos que optar. Muchos prefieren mantenerse fieles al pasado, dentro del cual se construyeron la figura de sí mismos, y repiten con el orgu-

54. Berdiagv, N., Esprit et Réalité, Paris 1943, p. 209ss; Id., Essai de Metaphisique eschatologique, Paris 1946; id., La liberación del hombre, etc.

Drevillon, J., Psychologie des groupes humains, Paris, 1973. 
llo de Dante: "si tengo que entrar en Florencia con la cabeza baja, no entraré en Florencia". Este es el drama de tantos "caballeros" fieles al pasado como Don Quijote. Se trata de una fidelidad externa que con frecuencia es una evasión ante la realidad presente, mezcla de orgullo, pereza mental, incapacidad y miedo a la verdad.

La fidelidad viva es diferente, ya que como S. Pablo, estima que hay que dejar a un lado el pasado y enfrentarse con el futuro (Filip. 3,13). Si S. Pablo no hubiese adoptado esa postura, la Iglesia no hubiera ido adelante: "mientras el fiel mediocre se mueve dentro de una religión exterior, que le ofrece un paisaje abstracto, indiferente, en el que los deberes son pesadas obligaciones, el fiel auténtico es aquel para quien Dios representa una presencia constante a lo largo del dia". Tal fidelidad se comprueba en el amor, en la amistad, en la ayuda a los demás, en la promoción de nuevos valores, en la llamada "comunicación". Kierkegaard ponia un ejemplo sorprendente: una novia piensa en su próximo matrimonio, porque en él ve su propia seguridad, su propia certidumbre; pero si ya se considerase segura, y se vistiera como "casada", su novio se sentiría defraudado: porque si ella no ama a otro, lo que es un punto casual, practica ya una infidelidad esencial. Es lo que decía S. Pablo: somos la esposa en el sentido semita: hemos sido desposados, pero no hemos sido llevados a la casa del Esposo y por ende, nunca estamos seguros (II Cor 1,22 y 5,5). La fidelidad es pues, la virtud fundamental, pero no puede ser lealtad a un partido aceptado de antemano, mera obstinación; tiene que ser fidelidad a una lealtad personal, y por ende fidelidad a sí mismo, según dijo Pascal: "la razón de tu fe es que seas fiel a ti mismo, la voz constante y renovada de tu razón, y no la de los demás". Tal es el drama actual. Muchos hablan de fidelidad, pero carecen de vida interior, carecen de sí mismos, viven extrañados y desentrañados ${ }^{55}$.

55. MaRTin DE GARDE, R., Les Tribault, Paris 1922-1929. 


\section{FIDELIDAD AL SINO PERSONAL.}

\section{La paradoja.}

La fidelidad a mí mismo entra quizá en conflicto con mi fidelidad a un grupo: me he comprometido. Puedo ser fiel a la palabra que di en un momento determinado, o a la voz constante y renovada de mi conciencia. Puedo hacer de la fidelidad una obstinación, fosilización, momificación, esclerosis, incapacidad de adaptación a la marcha de las circunstancias. Con frecuencia el problema es más grave, porque ha cobrado aspecto supersticioso en nombre de la religión. Hoy vemos gentes que no han estudiado la Sagrada Escritura y no la entienden: la citan contra los profesores de la Biblia, alegando ingenios supersticiosos. Nietzsche planteó ingeniosamente ese problema en el terreno del amor, cuando los amantes se prometen amor eterno y fidelidad eterna, diciendo post eventum: "mientras rn t.e ame, te ofreceré las demostraciones de mi amor; y si algún dí ya no te amo, seguirás recibiendo de mi las mismas demostraciones, pero por otros motivos: así podrás pensar que nada cambia”. Cuando un hombre ha vivido los años al servicio de una idea, es difícil que entienda la fidelidad a la evolución. Yo encuentro una explicación magnífica de este problema en la muerte del filósofo Ortega y Gasset.

La fidelidad implica por ende una previa sinceridad. Esta sinceridad obliga a estudiar atentamente el compromiso inicial con una idea dada, con un grupo, con una sociedad, etc. ¿No he abdicado, al comprometerme con un determinado grupo, movimiento, partido, con "los de la cuerda"? ¿Pero puedo vivir, sin comprometerme con algún grupo; aunque eso signifique un "sistema"? Entonces ya no soy libre, ni sincero, ni veraz, pues siempre expresaré ideas del grupo, no las mías propias. Así podríamos llegar al planteamiento de $G$. Marcel: “¿qué es un compromiso, sino una traición?”. No se necesitan fórmulas y juramentos externos para saber que alguien está comprometido con un grupo o movimiento: pero es claro que quien se compromete, renuncia ya a estudiarse a sí mismo: sólo utiliza la parte de sí mismo que es útil para el grupo ${ }^{56}$.

56. NIETzSche, F., Humain, trop humain, t. I, párr. 58, p. 92s. Ortega muere cambiado. Algún familiar estima que el filósofo no puede ni debe cambiar; pero Marañón replica: "al filósofo lo conocemos sus amigos". Cfr. MARTÍN DE GARD, R., Jean Barois, Paris 1931. 
2. Fidelidad y futuro.

Cuando alguien se compromete, no sabe lo que el futuro le revelará. Puede, pues, afirmar: "no aceptará ninguna revelación del futuro, sino que seguirá fiel al pasado y presente"; o puede afirmar: "seguirá fiel al pasado y presente, siempre que el futuro no me revele algo que me obligue a repensar el problema". Ambas actitudes pueden estudiarse en el terreno moral. Pero el problema es más profundo: las posibilidades creadoras del tiempo son la voluntad de Dios: oponerse a cambiar con el tiempo es ya oponerse a Dios: es decir: "iNi Dios podrá cambiarme!”.

También cabe la exageración contraria: el hombre que cambia sin cesar a merced del viento y de la luna como las olas del mar; Don Juan, fiel a sí mismo, va de una mujer a otra, pues las considera como "circunstancias" para ser fiel a sí mismo. ¿Cómo encontrar un medio justo de fidelidad entre el que se obstina en su idea (paranoico) y el que cambia como la veleta?, (esquizofrénico). Es un problema que pone en evidencia la incapacidad del hombre "natural" para resolver el problema existencial. Si nos entregamos al análisis racional, jamás llegaremos a ningún fin: cualquier abogado sabe que siempre hay veinte razones contra otras veinte, y que el proceso nunca llegará a la evidencia. Pero el aceptar una "decisión arbitraria" repugna, como algo irracional y absurdo. De ese modo, el problema se traslada al problema de la duda. ¿Puede el sujeto dudar de su propia vocación ya aceptada, y con la cual se ha comprometido con todo linaje de garantías? Para expresarlo del modo más duro y expresivo digamos: “¿cuál es el valor de un voto?”.

Quien pretenda hoy resolver ese problema, se encontrará entre dos extremos. Por un lado se le puede decir: "usted tiene razón, según la geometría del espíritu; pero el hecho es que miles y miles de hombres y mujeres piden la dispensa de votos". Por otro lado, se le puede decir: "usted pretende justificar con teorias, el espectáculo lamentable de los prófugos. Si no estaban "maduros", suya era la culpa" ${ }^{57}$.

57. MARCEL, Etre et Avoir... p. 56 ss. Es un profundo estudio de la fidelidad. También es excelente GusDorf, Traité... Nada podemos resolver definitivamente dentro de nosotros, ya que somos por esencia relacionales y trascendentes, a pesar de nuestro principio de absolutez 0 autoconsciencia. 
3. Fidelidad y sinceridad.

Los psicólogos estiman que una sinceridad completa es imposible. Sinceridad es pues un término aproximativo, que supone siempre "en cuanto cabe". Si, la sinceridad está en crisis, no es extraño que entre en crisis la fidelidad, que depende de ella. El compromiso irrevocable, el hombre de una pieza, que ve una línea recta y se entrega a ella, rechazando todas las desviaciones, debe meditar en el ejemplo de San Pedro: "iré contigo a la muerte"; dos horas más tarde: "no conozco a ese hombre". Quien se compromete con esa ingenuidad no ha valorado este mundo en que vive: mundo de ambigüedades de situación y de interpretación. Nunca sabrá exactamente por qué causas o motivos se comprometió, porque nunca volverá a vivir la misma situación, y en adelante todo será una nueva interpretación. Hoy tenemos a la vista material abundante en el terreno de la fidelidad conyugal y de la fidelidad monástica, y en general de toda fidelidad a instituciones fijas e inmóviles. Es fácil echar la culpa a la realidad, pero esa realidad es la voluntad de Dios, voluntad de beneplácito por lo general y sólo en casos comprobados voluntad de signo. Resulta pues, extraña la fidelidad a una idea, que no es la realidad, la voluntad de Dios. ¿Y qué importa la oposición a esta tesis, cuando la infidelidad conyugal y la infidelidad monástica, y las tradiciones de todo tipo reinan en el mundo? ¿Qué importa el que haya individuos ciegos, o fanáticos? Así se han creado tipos curiosos: manos limpias, pureza abstracta, mártires de una verdad sin comisión, sayones que calumnian, desuellan y guillotinan en aras de un silogismo, pero que no crean nada, ni realizan nada. Gritan con la Pasionaria: " Exterminio, exterminio, exterminio!”. ¿A quién obedecen y a quién sirven estos tipos, que niegan al tiempo la posibilidad de crear? No quieren crear ni progresar, ni reflexionan sobre su propia misión en el mundo. Estiman que su misión es vigilar el pasado y cortar el paso a todos los que pretendan sobrepasarlo. Es la fidelidad de la Inquisición ${ }^{58}$.

58. El problema de los sacerdotes contestatarios presenta caracteres nunca vistos en la Iglesia. También la crisis de vocaciones sacerdotales tiene hoy aires nuevos, por su universalidad, ya que afecta a todas las religiones del mundo. Es curioso el sacerdote contestatario, que se niega a abandonar la Iglesia, y se obstina en luchar dentro de ella con una extraña fidelidad a su ideal. Los contestatarios han organizado el "Consejo federal de grupos de Testimonio Cristiano"; en Paris, el 10 de noviembre de 1968, firmaron un manifiesto rudo. 
4. El sentido de la fidelidad.

Podemos presentar el aspecto negativo y el positivo de este problema. Es posible que un voto o compromiso responda a un ideal de pureza: ese ideal puede significar "manos limpias", acosmismo, renuncia a la acción, al contacto mundano. Así, los sacerdotes de Cibeles expresaban su ideal de pureza, como los gnósticos y maniqueos en general. Pensaban que es imposible ser puro y ser hombre integro, y preferian mutilar al hombre para que sea puro.

Pero la pureza tiene su aspecto positivo, como virtud relativa al ideal. El gnóstico creía ser fiel a Platón, pero Platón pedía que quien ha contemplado el mundo inteligible dé en este mundo sensible testimonio de lo que ha visto allá. La pureza negativa es infiel: al rechazar el mundo y su realidad, rechaza la creación divina, la voluntad de Dios, y confunde la naturaleza con el vicio, envolviendo a ambos en la misma condenación. Nunca se atrevería a proclamar sinceramente el ¡Oh felix culpa! ni a ensuciarse las manos por el triunfo del Reino. De ese modo, la pureza niega sus propios y maravillosos valores positivos, su fecundidad espiritual, su universalidad, su simpatía su alegría. Cuando la pureza es mal entendida, se convierte en un cepo, en el que caen los tristes.

Eso mismo acontece con el voto o compromiso en general, aunque no se pronuncie solemne, sino privada o secretamente. El individuo, que quizá no ha ponderado bien la situación, cae en la trampa, y en ella queda prisionero toda su vida. Quizá al fin estima que su voto consiste en una mera abstención externa, pero sin amor. El amor es el aspecto positivo. Quizá un día el prisionero estima que no nació para vivir en el calabozo, y que ahora está maduro para ver lo que antes no veía por carencia de conocimiento o libertad. Quizá quiere ahora dedicar su vida a la promoción del Reino de Dios activamente. ¿Pero, podrá hacerlo sin amor? Con el amor, la pureza y el voto superarían todos los aspectos negativos y darían

Nos consolamos fácilmente hablando de la inmensa mayoría silenciosa, de las extravagancias y novedades, pero el proceso está en marcha, y la crisis va invadiendo todos los sectores de la cultura progresivamente (Cfr. VERBIST, H., Les grandes controverses de l'Eglise contemporaine, Lausanne, 1971. Hay opiniones para todos los gustos, desde luego. Pero cada día se ve con mayor claridad que casi solo hay opiniones $*$ Informations catholiques internationales, n. 347, 1 nov. 1969. 
pruebas de fecundidad. Sin el amor, ni en el calabozo ni en la plaza es posible ser fieles a Dios ${ }^{59}$.

\section{Fidelidad y amor.}

Fidelidad, pureza, probidad, temor de Dios, honor, dignidad, honradez, rectitud y demás virtudes totalitarias, constituyen la escolta del amor, y reciben sentido del amor. En todas ellas deberá reflejarse el amor, si son auténticas. La ausencia o precariedad de la escolta demuestra la ausencia del amor.

San Agustín analizó ese punto, al estudiar el problema del "temor" en dos esposas que temen a su marido. La primera teme al marido, porque le ama: teme que se canse, que se vaya, que se aburra en casa, que se vaya de viaje y que tarde en regresar. La segunda teme a su marido, porque no le ama. Ama a un extraño, aunque nunca ha pecado con él ni pecará externamente, pues teme a su marido: teme que su marido se entere, que obre premeditadamente para sorprenderla. La primera es fiel, la segunda es infiel dentro del corazón. Y lo mismo podríamos comprobar en todas esas virtudes de la escolta del amor. Del corazón sale el mal pensamiento, el homiciaio, el adulterio, la fornicación, el hurto, la calumnia, la blasfemia, y esto es lo que mancha al hombre (Mt 15,19).

Ya los primeros cristianos tuvieron que comprender el problema de las vírgenes atormentadas y violadas por los sayones o por los bárbaros. Los Santos Padres contrapusieron a la integridad física una integridad interior, que nadie puede violar, sino la infidelidad misma. Por eso la pureza y la fidelidad interiores son casi idénticas y constituyen el corazón del espíritu humano: de ahí salen el bien y el mal, los frutos buenos y los malos, según sean las intenciones injertadas en el tronco del amor.

La fidelidad no es un problema del Código. Quien mantiene la fidelidad tan solo por temor al Código, es ya infiel en su corazón. E1 voto religioso y el contrato matrimonial pierden su típico valor de sacrificio, cuando ya no son expresión del amor, cuando no caminan en la escolta del amor. Ya no son un homenaje, sino un cumplimiento: se han sustraido al ordenamiento del amor ${ }^{60}$.

59. Bálthasar, J. U. von, La gloire et la Croix, II, Paris 1968; id., Glaubhaft ist nur die Liebe, Einsiedeln, 2 ed., 1963.

60. Berdiaev ha implantado su espritualidad sobre la teoria del "acto creador", que constituye su esencia. El asceta es pues como un "po- 
6. Los grados de la fidelidad y la fidelidad.

La fidelidad admite muchos tipos de compromiso, muchos grados de tiempo, lugar, circunstancias y gravedad: no es lo mismo entrar en un barco, para una travesía, que entrar en el matrimonio, en el convento; o en el ergástulo de los mártires. Pero la fidelidad es una postura absoluta, y sus compromisos son absolutos. Un compromiso condicional, subjuntivo, potencial, no es un compromiso, sino una hipótesis. Se ordena pues la fidelidad, como se ordena el amor, que la anima.

¿Cómo puede mantenerse la fidelidad en tantos grados y variaciones y en especial en épocas de crisis como la nuestra? No parece posible, si no se siente el hálito del amor. Pero aun contando con el impetu creador de la caridad, es menester educar o formar la fidelidad. Porque ella reclama una perpetua imaginación creadora, para superar los conflictos que pueden estallar hoy o mañana. Pueden llegar momentos tan difíciles, que la fidelidad no encuentra ya algo así como "motivos de credibilidad". ¿Y entonces?

Entonces queda Dios. Precisamente se hace llamar "El Amén", el que cumple siempre sus promesas, sus palabras, sus planes. Cuando los hagiógrafos presentan una situación que parece desesperada, porque las infidelidades del pueblo reclaman la cólera de Dios y la desencadenan, ponen en boca de Moisés la última oración posible: "ten piedad, Jahvé, por fidelidad a ti mismo". De esa postura se aprovechaban los israelitas para recordarle siempre al Señor su promesa, su alianza, su compromiso, si asi puede hablarse. $Y$ aunque Dios reclamaba siempre su propia libertad, y denunciaba la mala fe del pueblo, éste continuaba confiando siempre en la fidelidad del Señor. Los hagiógrafos y los mismos profetas ya no saben qué más decir, y se colocan entre el pueblo y Dios, confundiéndose unas veces con el pueblo y otras con Dios.

seído" por Dios, un entusiasta, en el sentido etimológico. Cuando S. Pablo dice que el amor de Dios se derrama en nuestros corazones (Rom. 5,5) piensa en los carismas, que aparecen cuando se recibe el Espíritu Santo. El amor de Dios produce pues profetas, inspirados, activistas, creadores. Por eso se lamenta Berdiaev de que el racionalismo teológico haya ido eliminando el espíritu profético, reduciéndose a aspectos negativos. Cfr. Essai... p. 204ss., también se lamenta del "espíritu de legalidad". Cfr. id., Esprit et realité, p. 204-248; por eso exalta tanto la "ética del acto creador. Cfr. id., La destinaciön del hombre, 178-211. 
Por eso, algunos autores modernos recitan la fórmula: "sé fiel a ti mismo"! En efecto, quien engaña a otro, se engaña también a sí mismo. Por muy confusa que sea la situación actual, la fidelidad ha de ser absoluta, porque es amor ${ }^{61}$.

\section{Lope Cilleruelo}

61. De ese modo tenemos dos soluciones. La solución teológica es en el fondo la que utilizaba Israel: "Por el honor de tu nombre, escúchanos, Señor". Algunos teólogos han llamado a la Virgen María "Omnipotencia suplicante": eso indica que todos podemos ser un poco de omnipotencia suplicante, si utilizamos el método de Israel, y nos apoyamos en la fidelidad de Dios a sus promesas, a su palabra, a su plan, al amor que nos ofrece continuamente. Nuestro pecado consiste en confiar en nosotros mismos, en mantener la arrogancia de Pedro en la última Cena. La solución científica, psicológica y sociológica, es la que utilizan ciertos humanistas: "ser fieles a nosotros mismos", como Israel era en el fondo fiel a si mismo. De ese modo, entre bendiciones y castigos, Dios sigue desenvolviendo una historia de la salvación. 